

OECD Economics Department Working Papers No. 1493

Limits to government debt sustainability in middleincome countries

\author{
Jean-Marc Fournier, \\ Manuel Bétin
}


ECONOMICS DEPARTMENT

Cancels \& replaces the same document of 23 July 2018

\section{LIMITS TO GOVERNMENT DEBT SUSTAINABILITY IN MIDDLE-INCOME COUNTRIES}

ECONOMICS DEPARTMENT WORKING PAPERS No. 1493

\section{By Jean-Marc Fournier and Manuel Bétin}

OECD Working Papers should not be reported as representing the official views of the OECD or of its member countries. The opinions expressed and arguments employed are those of the author(s).

Authorised for publication by Alain de Serres, Deputy Director, Policy Studies Branch, Economics Department.

Document available in pdf format only.

All Economics Department Working Papers are available at www.oecd.org/eco/workingpapers

JT03439343 
OECD Working Papers should not be reported as representing the official views of the OECD or of its member countries. The opinions expressed and arguments employed are those of the author(s).

Working Papers describe preliminary results or research in progress by the author(s) and are published to stimulate discussion on a broad range of issues on which the OECD works.

Comments on Working Papers are welcomed, and may be sent to OECD Economics Department, 2 rue André-Pascal, 75775 Paris Cedex 16, France, or by e-mail to eco.contact@oecd.org.

All Economics Department Working Papers are available at www.oecd.org/eco/workingpapers.

On 3 May 2018, the OECD Council invited Lithuania to become a Member. At the time of preparation, the deposit of Lithuania's instrument of accession to the OECD Convention was pending and therefore Lithuania does not appear in the list of OECD Members and is not included in the OECD zone aggregates.

On 25 May 2018, the OECD Council invited Colombia to become a Member. At the time of preparation, the deposit of Colombia's instrument of accession to the OECD Convention was pending and therefore Colombia does not appear in the list of OECD Members and is not included in the OECD zone aggregates.

This document and any map included herein are without prejudice to the status of or sovereignty over any territory, to the delimitation of international frontiers and boundaries and to the name of any territory, city or area.

(C) OECD (2018)

You can copy, download or print OECD content for your own use, and you can include excerpts from OECD publications, databases and multimedia products in your own documents, presentations, blogs, websites and teaching materials, provided that suitable acknowledgment of OECD as source and copyright owner is given. All requests for commercial use and translation rights should be submitted to rights@oecd.org 
ECO/WKP(2018)41

\section{Abstract/Résumé \\ Limits to government debt sustainability in middle-income countries}

This paper investigates the effect of structural characteristics on debt limits of middle income countries. Two equations relate the probability of default to the interest rate. First, the probability of default is estimated with a logit model. Second, the assumption of non-arbitrage opportunity on the sovereign bond market relates the interest rate, the probability of default and the recovery rate. This model leads to three situations: a single and stable solution at low debt, multiple equilibria with stable and unstable solutions at intermediate debt, and a single solution with dissuasively high risk-premium beyond a debt threshold: this defines the debt limit. It reflects the empirical evidence on default determinants: it increases with perceived government effectiveness, the export to GDP ratio and the expected recovery rate and decreases with the commodity export to GDP ratio, the size of growth shocks, the share of defaults in neighbouring countries, the risk-free rate and investors' risk aversion. Debt limits are highly sensitive to the expected recovery rate, reflecting the importance of credibility. The multiple equilibria case illustrates the risk of self-fulfilling crises: interest rate shocks can trigger the default below the debt limit.

Key words: public debt, debt limit, sovereign default, government effectiveness, institutions

JEL Classification: E62 ; H63 ; F34

***** $*$

\section{Limites à la soutenabilité de la dette publique dans les pays émergents}

Cet article étudie l'effet des caractéristiques structurelles d'une économie sur la limite de l'endettement public des économies émergentes. Deux équations relient la probabilité de défaut souverain au taux d'intérêt. D'une part, la probabilité de défaut est estimée par un modèle logit. D'autre part, l'hypothèse de non-arbitrage sur le marché de la dette souveraine assure l'existence d'un lien entre taux d'intérêt, probabilité de défaut et taux de recouvrement en cas de défaut. Ce modèle débouche sur trois scenarii: une solution unique et stable à un niveau d'endettement faible, une zone à équilibres multiples avec des solutions stables et instables à un niveau intermédiaire, et une solution unique, associée à une prime de risque dissuasive au-delà d'un seuil qui définit la dette limite. Le niveau de cette limite reflète le rôle des déterminants empiriques des défauts. Il augmente avec la perception de l'efficacité du gouvernement, le ratio des exportations au PIB, et le taux de recouvrement anticipé et diminue avec la part des exportations de matières premières dans le PIB, la taille des chocs de croissance, les défauts de pays voisins, le taux d'intérêt sans risque et le degré d'aversion pour le risque des investisseurs. Les dettes limites sont particulièrement sensibles au niveau anticipé du recouvrement en cas de défaut, ce qui souligne l'importance de la crédibilité. Par ailleurs, le scenario à équilibres multiples illustre le risque de crise autoréalisatrice pour lequel un choc de taux d'intérêt peut déclencher un défaut à un niveau de dette inférieur à la limite.

Mots clés: dette publique, dette limite, défaut souverain, efficacité du gouvernement, institutions

Classification JEL: E62 ; H63 ; F34 


\section{TABLE OF CONTENTS}

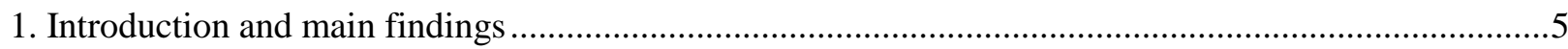

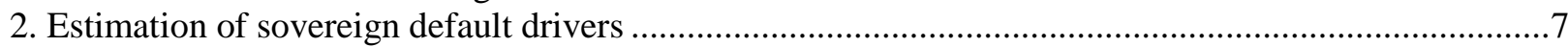

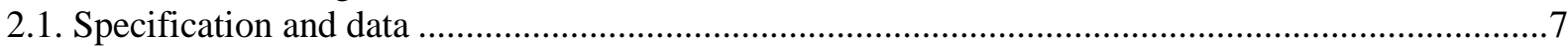



3. A simple model linking the debt level, the interest rate and the default probability .............................11

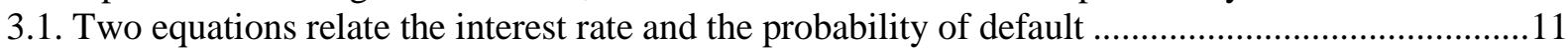

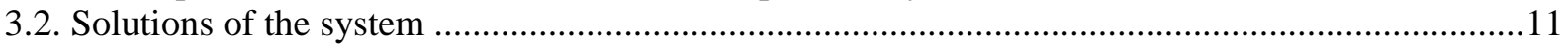



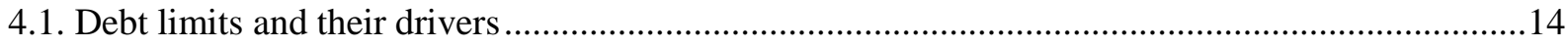





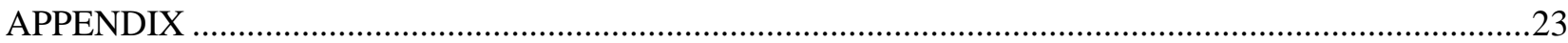

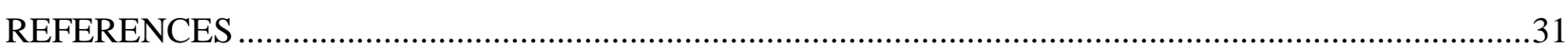

\section{Tables}

1. Logistic regression: Estimating default probability determinants...............................................10

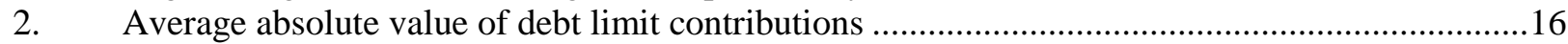

A1.1. Alternative regressions controlling for different institutional variables ....................................23

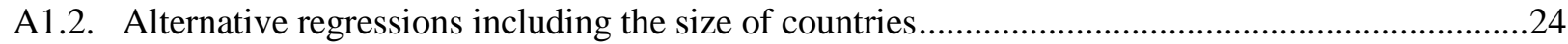

A1.3. Alternative regressions using different interest payment concepts ...........................................25

A1.4. Alternative regressions controlling for exchange rate regimes .................................................26

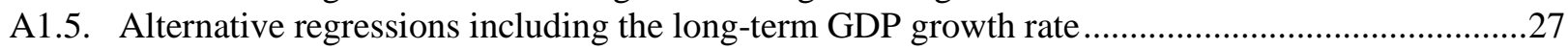

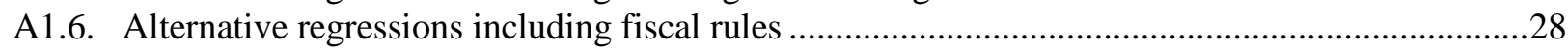

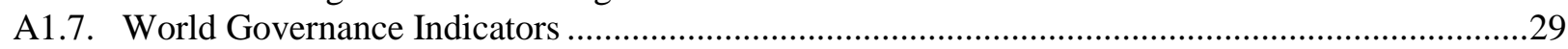



\section{Figures}



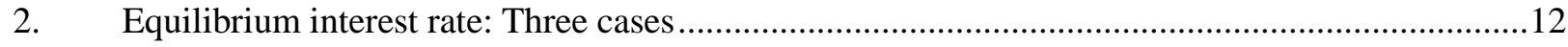

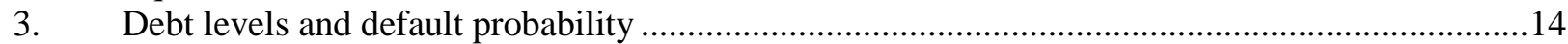

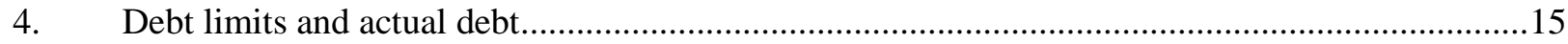

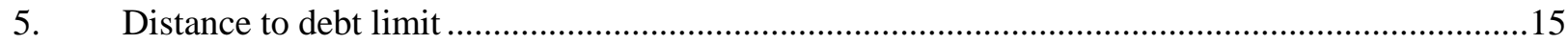

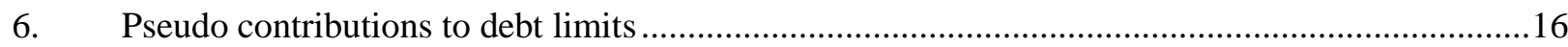



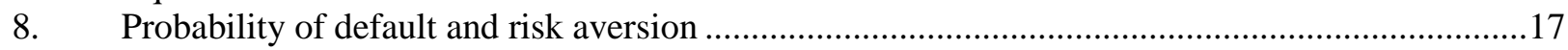

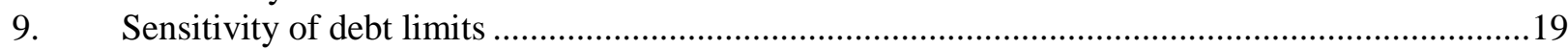

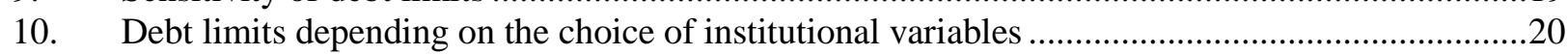



12. Estimated probability of default are correlated with sovereign ratings........................................22 
ECO/WKP(2018)41

\title{
LIMITS TO GOVERNMENT DEBT SUSTAINABILITY IN MIDDLE-INCOME COUNTRIES
}

\author{
Jean-Marc Fournier and Manuel Bétin ${ }^{1}$
}

\section{Introduction and main findings}

1. With rising public debt after the global financial crisis, a new strand of literature has assessed the limits to government debt sustainability. In advanced economies, given the scarcity of default events, model-based approaches have been used by Bi (2012), Bi and Leeper (2013), Ghosh et al. (2013), Botev et al. (2016) and Fournier and Fall (2017). This focus on debt limits complements the literature on fiscal sustainability that considers not only the debt ratio, but also the primary balance that governments can sustainably maintain (as in Blanchard et al., 1990).

2. In the case of emerging economies, defaults have been more frequent, and hence more empirical work has been done to identify default determinants, shedding a complementary light on debt sustainability (see Villemot, 2012, for a literature review). For instance, Reinhart et al. (2003) find evidence that a country's default history matters, coining the phrase "debt intolerance", and Kohlscheen (2007) argues that the explanation for the serial defaults by a number of sovereign borrowers lies in their constitutions. Kraay and Nehru (2006) provide evidence on the effect of institutions on top of other determinants on external debt defaults. Catão and Kapur (2004) provide a different explanation, highlighting that the external debt to export ratio and the volatility of output matter, and in the presence of the latter, they find no significant effect of default history. Hilscher and Nosbusch (2010) highlight the role of term of trade volatility. Panizza et al. (2009) discuss the relative weakness of public debt contracts, with enforcement mechanisms that differ from those of private debt contracts. More recently, Arellano et al. (2017) point to the importance of contagion.

3. This paper takes advantage of the information available on past defaults of middle-income countries to derive debt limits from empirical evidence. This complements the recent literature on debt limits in advanced economies that could not be derived from estimates of default determinants in the absence of available information. The sample does not include low-income countries as their public debt can include a large share of concessional debt that is not directly driven by market forces and in the case that this concessional lending is successful in stimulating growth, this may improve debt sustainability as discussed by Reisen and Ndoye (2008). The empirical estimates are parsimonious and focus on long-term determinants so as to identify the structural drivers of debt limits.

1. Jean-Marc Fournier and Manuel Bétin were both members of the OECD Economics Department when this document was prepared. They thank Sónia Araújo, Boris Cournède, Vitor Gaspar, Peter Hoeller, Isabelle Joumard, Paulo Mauro, Angel Melguizo, Alvaro Pereira, David Turner, Gert Wehinger and participants in an internal seminar for helpful comments and suggestions. Thanks also go to Celia Rutkoski's excellent support for preparing this document. 
4. The debt limit calculated in this paper corresponds to the level of debt that triggers a discontinuous jump at the lowest possible equilibrium interest rate and pushes the probability of default close to one. This debt threshold is the product of the endogenous interaction between the interest rate and the probability of default. The equilibrium is the result of two equations. One is providing the intrinsic default probability of a country as a function of the interest rate and conditional on debt and other country characteristics. The other one is the link between the interest rate and the probability of default in the absence of arbitrage, so that the risk premium offsets the default risk from the investors' side. For a debt range that depends on each country's characteristics, there is an intermediate stage in which there are several solutions, one of them with a moderate probability of default and another with a default probability close to one that corresponds to a self-fulfilling crisis of a solvent debtor. This is similar to the selffulfilling liquidity crisis zone described in Cole and Kehoe (2000). An increase in the debt level shifts the curve associated with the intrinsic default probability equation up. Beyond a critical level, the low default probability solution vanishes and a single solution is left with a default probability very close to one.

5. A simple model cannot capture reality, which is much more complex. Analysing debt limits of a particular country requires more information beyond the data embedded in the stylised model to identify additional upward or downward risks surrounding the indicative debt limits provided in this paper. Moreover, the debt limits can change somewhat with parameters that can be delicate to estimate or calibrate. Practitioners are thus encouraged to combine such analysis with country-specific detailed investigations.

6. The effect of debt, the interest rate burden and other drivers of defaults are estimated, so that debt limits are built on the information revealed by past defaults in middle-income countries. Noticeable improvements in data collection help to refine the empirical evidence on the drivers of sovereign defaults that covers both external and internal defaults on government debt, with data provided by Reinhart and Rogoff (2009) for defaults and the IMF Historical Public Debt Database following Abbas et al. (2010) for debt. The inclusion of internal defaults sheds new light on the analysis of sovereign default as most of the literature focuses on external debt (Reinhart and Rogoff, 2009). Including both internal and external debt makes it possible to consider a solvency analysis that takes into account all commitments.

7. The main results emerging from the analysis are the following:

- Debt limits vary substantially across countries and are mainly driven by differences in export ratios and the perception of the effectiveness of the government.

- The model illustrates the risk of a self-fulfilling crisis in the absence of a lender of last resort. At intermediate levels of debt, an exogenous interest rate shock may trigger a self-fulfilling crisis below the debt limit.

- Credibility of the government and the expected strength of the legal enforcement of debt contracts are essential. This is illustrated here with the sensitivity of the debt limit to the recovery rate. The limit case of an expected recovery rate equal to one can be seen as a stylised case of perfectly credible government: if investors face no risk of portfolio loss, the sovereign is able to accumulate more debt.

- Beyond government effectiveness, other institutional features such as the rule of law, regulatory quality, political stability, voice and accountability and control of corruption are also highly correlated with default episodes and should be considered when assessing sovereign risk. 


\section{Estimation of sovereign default drivers}

\subsection{Specification and data}

8. The probability of default $p_{i, t}$ of country $i$ in year $t$ is assumed to follow a logistic model in which the risk of default is increasing with the lagged debt to GDP ratio $d_{i, t-1}$, the government interest payment to export ratio $r_{i, t-1} d_{i, t-2} / e_{i, t-1}$ where $r_{i, t-1}$ is the effective interest rate and $e_{i, t-1}$ the export to GDP ratio and a set of structural variables $X_{i, t-1}$ including government effectiveness, the ratio of mining and oil exports to GDP and the size of growth shocks. As this equation relates the probability of default to the backward looking lagged effective interest rate, it reflects the propensity of governments to repay, conditional on an interest rate level that does not take into account the latest market developments.

$$
\begin{aligned}
p_{i, t} & =\mathrm{P}\left(\varepsilon_{\mathrm{i}, \mathrm{t}}<\beta_{0}+\beta_{X} X_{i, t-1}+\beta_{r} r_{i, t-1} d_{i, t-2} / e_{i, t-1}+\beta_{d} d_{i, t-1}\right) \\
& =\frac{1}{1+e^{-\left(\beta_{0}+\beta_{X} X_{i, t-1}+\beta_{r} r_{i, t-1} d_{i, t-2} / e_{i, t-1}+\beta_{d} d_{i, t-1}\right)}}
\end{aligned}
$$

9. The sample is an unbalanced panel data set of 21 middle-income countries from 1980 to 2010 , selected on the basis of GDP per capita at purchasing power parity and data availability. Such a sub-sample is likely to be more homogenous than a world-wide panel, so that the usual assumption that estimated coefficients are constant across the sample is more credible. The specification does not include the lagged dependent variable because these estimates will be used to find a structural equilibrium between the probability of default and the interest rate, ignoring short-term deviations from this equilibrium. Fournier and Bétin (2018) provide quite similar results with three lags of the dependent variable and a broader country sample.

10. Reinhart and Rogoff's (2009) default data include government defaults on both external and internal debt. Sovereign default "episodes include instances in which rescheduled debt is ultimately extinguished in terms less favourable than the original obligation." In addition, domestic debt default includes "the freezing of bank deposits and/or forcible conversions of such deposits from dollars to local currencies". Defaults were more frequent before the mid-1990s (Figure 1). The IMF Historical Public Debt Database used here also includes both external and domestic debt (Abbas et al., 2010).

Figure 1. Sovereign crises in middle-income countries

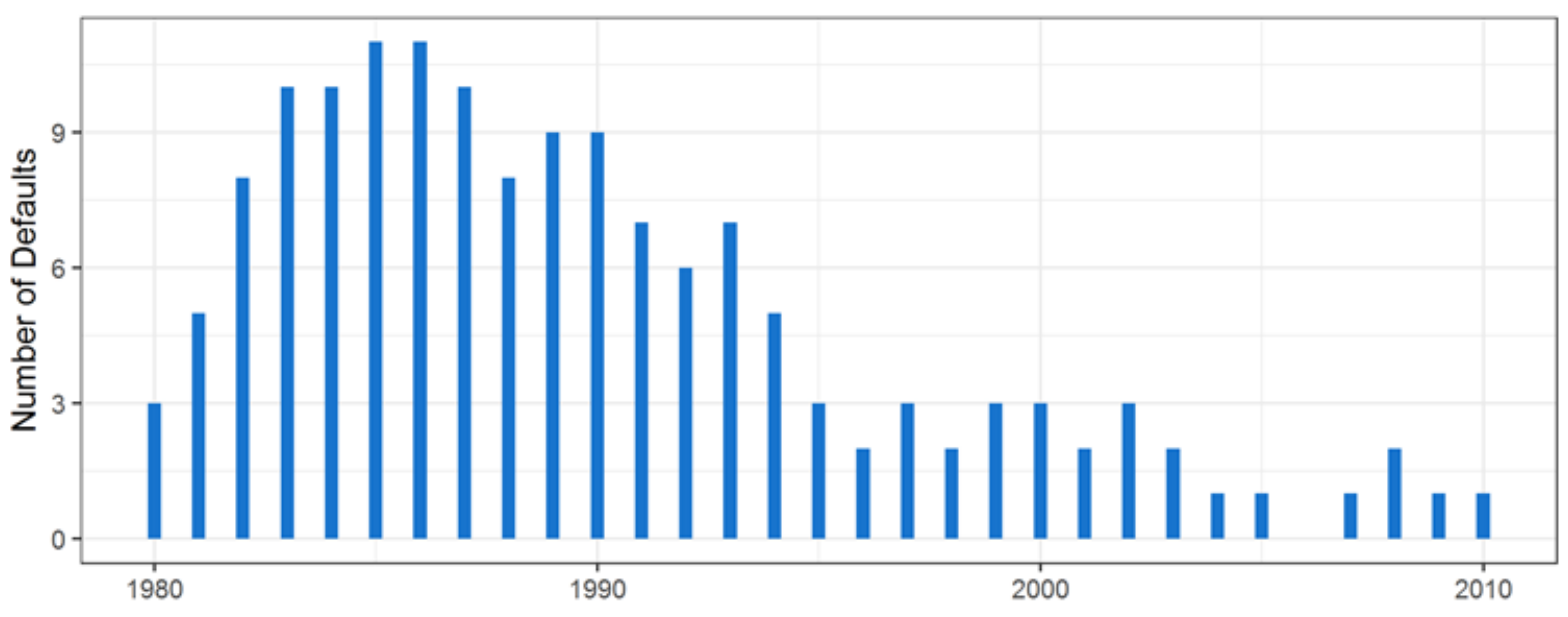

1. Sovereign crises include both domestic and external defaults for a sample of 21 middle-income countries.

Source: Reinhart and Rogoff (2009). 
11. The government effectiveness index (as well as all other institutional variables) is a perception index from the Worldwide Governance Indicators database (WGI) disseminated by the World Bank. It captures "perceptions of the quality of public services, the quality of the civil service and the degree of its independence from political pressures, the quality of policy formulation and implementation, and the credibility of the government's commitment to such policies" (Kaufmann, 2011). Government effectiveness is included as a country average over time due to the shorter sample. Because this indicator has very low within-country variation, the average over the period 1996-2010 is regarded as a good proxy for government effectiveness for the entire period.

\subsection{Estimation results}

12. The baseline specification used to calculate debt limits includes key structural default determinants, informed by the literature, and is quite parsimonious (Table 1, column 1). Results are fairly robust to alternative sets of explanatory variables (other columns in Table 1 and Appendix). Further alternative specifications with a broader country sample reported in Fournier and Bétin (2018) confirm that the key findings reported here are quite robust.

13. The estimation results show that the debt burden is a significant determinant of default (Table 1). Concerning the other drivers:

- As growth is a driver of the debt-to GDP dynamic, higher real growth reduces the default risk. This result is in line with most of the literature and suggests a strong relationship between sovereign default and the business cycle. As shown by Viennot (2017) among others, defaults happen mostly during economic downturns. The effect of real GDP growth is robust to the inclusion of the average GDP growth rate during a 1, 2, 3, 4 and 5 year window (Table A1.5).

- A higher interest payment burden raises the default probability. In line with many papers in the literature (e.g. Kraay and Nehru, 2006), the interest payment burden is captured here by the government interest payment to export ratio. This captures in particular the capacity of the country to repay interest payments denominated in foreign currency. Interest payments include both domestic and external debt to ensure consistency with the default and debt data.

- The dependency of the economy on oil and mining exports raises the default probability as do the number of defaults on the continent in which a country is situated and the size of growth shocks. Regarding the effect of the dependency on commodity exports there is evidence for oil and mining export dependency. Alternative tests not reported here reveal no significant effect for agricultural product export dependency.

- The effect of government effectiveness on the default probability is negative, and the magnitude is similar to that found by Fournier and Bétin (2018) with a time-varying indicator and a broader country sample. This may be because greater government effectiveness can increase long-term growth prospects (Acemoglu et al., 2005), reliance on equity-like liabilities (Faria and Mauro, 2009) and the capacity to raise taxes (Akgun et al., 2017), while a better perception of government effectiveness reduces the risk of self-fulfilling crises. The government effectiveness indicator has so far not been used in empirical work on sovereign defaults. The evidence of the impact of institutional quality on the probability of default has so far been explored using a broad-based indicator encompassing both institutions and policies, the CPIA (Country Policy and Institution Assessment) in Kraay and Nehru (2006), Cohen and Valadier (2012) and Viennot (2017). 
14. Alternative regressions shed light on the role of other determinants and on robustness. History of default and terms of trade volatility are not significant (Column 2 and 6). The third column shows that in the presence of the government effectiveness indicator, the logarithm of the GDP per capita level is not a significant determinant: countries do not default because they are poor, but because their institutions are weak (Fournier and Bétin, 2018, find no robust effect of logarithm of GDP per capita with a broader country sample). The fourth column shows that beyond the debt level, its dynamic captured here by the change has a positive but not significant effect. In the fifth column, the primary balance is not significant, which may reflect a lack of information as data coverage is more limited. The seventh column shows that the interest payment to GDP ratio is not significantly linked to default, in contrast with the interest payment to export ratio (see Annex Table A1.3 for additional robustness checks with alternative concepts capturing the interest payment burden). The eighth column shows that openness is not significant if it is not interacted with the interest payment burden while the ninth column provides evidence of a negative but not significant effect of the tax raising capacity proxied by the public revenue to GDP ratio.

15. In the Annex Table A1.2, specifications with the logarithm of population or the logarithm of GDP suggest that country size does not play any significant role. This table includes tests of the effect of an interaction between size and the interest payment to export ratio and this interaction term is not significant either. Additional specifications reported in Annex Table A1.4 provide weak evidence of an effect of exchange rate changes and no evidence of the exchange rate regime on the probability of default. The existence of a debt rule has a negative effect in this sample, while a budget balance rule is associated with a non-significant higher probability of default, potentially reflecting an endogeneity bias: more fragile countries can have been under stronger pressure to set up such a rule (Table A1.6). In addition, the results of a specification including both the debt-to-GDP ratio and its square (not reported), are not significant for both variables, suggesting that the baseline logit specification without such a square is appropriate: no significant deviation from the logistic function emerges at high debt levels. 


\section{ECO/WKP(2018)41}

Table 1. Logistic regression: Estimating default probability determinants

\begin{tabular}{|c|c|c|c|c|c|c|c|c|c|}
\hline & (1) & (2) & (3) & (4) & (5) & (6) & (7) & (8) & (9) \\
\hline Gross debt to GDP & $\begin{array}{c}2.19^{* * *} \\
(0.67)\end{array}$ & $\begin{array}{c}3.86^{* * *} \\
(0.92)\end{array}$ & $\begin{array}{c}3.86^{* * *} \\
(0.68)\end{array}$ & $\begin{array}{c}2.14^{* * *} \\
(0.68)\end{array}$ & $\begin{array}{l}3.50^{* *} \\
(1.42)\end{array}$ & $\begin{array}{c}2.22^{* * *} \\
(0.68)\end{array}$ & $\begin{array}{c}2.39^{* * *} \\
(0.71)\end{array}$ & $\begin{array}{c}2.47^{\star * *} \\
(0.75)\end{array}$ & $\begin{array}{c}4.07^{* * *} \\
(1.33)\end{array}$ \\
\hline $\begin{array}{l}\text { Change in gross debt } \\
\text { to GDP }\end{array}$ & & & & $\begin{array}{c}2.51 \\
(1.60)\end{array}$ & & & & & \\
\hline Real GDP growth & $\begin{array}{c}-13.41^{\star * *} \\
(3.81)\end{array}$ & $\begin{array}{l}-8.50^{*} \\
(4.67)\end{array}$ & $\begin{array}{c}-13.38^{\star * *} \\
(3.83)\end{array}$ & $\begin{array}{l}-9.66^{* *} \\
(4.34)\end{array}$ & $\begin{array}{c}-14.31^{* *} \\
(6.14)\end{array}$ & $\begin{array}{c}-13.30^{* * *} \\
(3.82)\end{array}$ & $\begin{array}{c}-15.16^{\star * *} \\
(3.43)\end{array}$ & $\begin{array}{c}-13.53^{\star * *} \\
(3.81)\end{array}$ & $\begin{array}{c}-16.06^{* *} \\
(6.14)\end{array}$ \\
\hline $\begin{array}{l}\text { Log GDP per capita } \\
\text { in PPP }\end{array}$ & & & $\begin{array}{l}-0.31 \\
(0.36)\end{array}$ & & & & & & \\
\hline $\begin{array}{l}\text { Interest payments } \\
\text { to exports }\end{array}$ & $\begin{array}{l}3.27^{\star *} \\
(1.30)\end{array}$ & $\begin{array}{c}0.34 \\
(1.91)\end{array}$ & $\begin{array}{l}3.43^{\star * *} \\
(1.32)\end{array}$ & $\begin{array}{l}2.90^{* *} \\
(1.33)\end{array}$ & $\begin{array}{c}2.43 \\
(2.91)\end{array}$ & $\begin{array}{l}3.21^{* *} \\
(1.30)\end{array}$ & & $\begin{array}{l}2.76^{*} \\
(1.42)\end{array}$ & $\begin{array}{c}0.46 \\
(2.89)\end{array}$ \\
\hline $\begin{array}{l}\text { Interest payments } \\
\text { to GDP }\end{array}$ & & & & & & & $\begin{array}{c}1.73 \\
(6.89)\end{array}$ & & \\
\hline $\begin{array}{l}\text { Government } \\
\text { effectiveness }\end{array}$ & $\begin{array}{c}-1.77^{* \star *} \\
(0.39)\end{array}$ & $\begin{array}{c}-2.60^{\star \star \star} \\
(0.58)\end{array}$ & $\begin{array}{c}-1.73^{\star \star \star} \\
(0.40)\end{array}$ & $\begin{array}{c}-1.79^{\star \star \star} \\
(0.40)\end{array}$ & $\begin{array}{c}-3.62^{* * *} \\
(1.38)\end{array}$ & $\begin{array}{c}-1.84^{\star * *} \\
(0.42)\end{array}$ & $\begin{array}{c}-1.39^{* * *} \\
(0.35)\end{array}$ & $\begin{array}{c}-1.62^{\star * *} \\
(0.43)\end{array}$ & $\begin{array}{c}-3.78^{\star \star *} \\
(1.45)\end{array}$ \\
\hline $\begin{array}{l}\text { Oil and mining exports } \\
\text { to GDP }\end{array}$ & $\begin{array}{l}8.27^{* *} \\
(3.94)\end{array}$ & $\begin{array}{c}4.98 \\
(5.02)\end{array}$ & $\begin{array}{l}7.49^{\star} \\
(4.05)\end{array}$ & $\begin{array}{l}8.35^{\star \star} \\
(3.93)\end{array}$ & $\begin{array}{c}-5.05 \\
(10.86)\end{array}$ & $\begin{array}{l}8.18^{* *} \\
(3.93)\end{array}$ & $\begin{array}{c}5.79 \\
(3.65)\end{array}$ & $\begin{array}{l}9.98^{\star *} \\
(4.46)\end{array}$ & $\begin{array}{c}-5.88 \\
(10.89)\end{array}$ \\
\hline $\begin{array}{l}\text { Number of defaults } \\
\text { in the region }\end{array}$ & $\begin{array}{l}0.30^{\star * *} \\
(0.04)\end{array}$ & $\begin{array}{c}0.32^{\star * *} \\
(0.05)\end{array}$ & $\begin{array}{l}0.29^{* * *} \\
(0.04)\end{array}$ & $\begin{array}{l}0.31^{* * *} \\
(0.04)\end{array}$ & $\begin{array}{l}-0.26 \\
(0.17)\end{array}$ & $\begin{array}{l}0.31^{\star * *} \\
(0.04)\end{array}$ & $\begin{array}{l}0.29^{* * *} \\
(0.03)\end{array}$ & $\begin{array}{l}0.29^{* * *} \\
(0.04)\end{array}$ & $\begin{array}{l}-0.19 \\
(0.15)\end{array}$ \\
\hline $\begin{array}{l}10 \text { year real GDP } \\
\text { volatility }\end{array}$ & $\begin{array}{c}33.59^{\star * *} \\
(8.32)\end{array}$ & $\begin{array}{c}40.50^{* * *} \\
(9.89)\end{array}$ & $\begin{array}{c}34.76^{* * *} \\
(8.49)\end{array}$ & $\begin{array}{c}36.85^{\star * *} \\
(8.65)\end{array}$ & $\begin{array}{c}48.65^{\star * \star} \\
(16.65)\end{array}$ & $\begin{array}{c}35.33^{\star \star *} \\
(9.20)\end{array}$ & $\begin{array}{c}38.12^{\star \star \star} \\
(7.93)\end{array}$ & $\begin{array}{c}31.81^{* * *} \\
(8.52)\end{array}$ & $\begin{array}{r}58.63^{* * *} \\
(15.95)\end{array}$ \\
\hline $\begin{array}{l}10 \text { years terms of trade } \\
\text { volatility }\end{array}$ & & $\begin{array}{l}-4.55 \\
(5.16)\end{array}$ & & & & & & & \\
\hline Primary fiscal balance & & & & & $\begin{array}{c}14.72 \\
(14.62)\end{array}$ & & & & \\
\hline $\begin{array}{l}\text { Share of years in default } \\
\text { in the last } 10 \text { years }\end{array}$ & & & & & & $\begin{array}{l}-0.25 \\
(0.56)\end{array}$ & & & \\
\hline Trade openness & & & & & & & & $\begin{array}{l}-0.99 \\
(1.16)\end{array}$ & \\
\hline Revenue ratio & & & & & & & & & $\begin{array}{l}-6.00 \\
(4.78)\end{array}$ \\
\hline Constant & $\begin{array}{l}-6.52^{\star \star \star} \\
(0.68)\end{array}$ & $\begin{array}{c}-7.36^{\star \star \star} \\
(0.89)\end{array}$ & $\begin{array}{l}-4.56^{*} \\
(2.36)\end{array}$ & $\begin{array}{l}-6.78^{\star \star \star} \\
(0.73)\end{array}$ & $\begin{array}{l}-6.36^{* \star *} \\
(1.34)\end{array}$ & $\begin{array}{c}-6.56^{\star * *} \\
(0.69)\end{array}$ & $\begin{array}{c}-5.90^{\star * *} \\
(0.60)\end{array}$ & $\begin{array}{c}-6.06^{\star * *} \\
(0.85)\end{array}$ & $\begin{array}{c}-5.65^{\star * *} \\
(1.59)\end{array}$ \\
\hline Observations & 531 & 428 & 531 & 520 & 307 & 531 & 553 & 531 & 342 \\
\hline Log Likelihood & -131.27 & -94.36 & -130.92 & -128.33 & -41.33 & -131.17 & -154.84 & -130.89 & -44.68 \\
\hline Akaike Inf. Crit. & 278.54 & 206.72 & 279.84 & 274.66 & 100.66 & 280.34 & 325.68 & 279.78 & 107.36 \\
\hline
\end{tabular}

Note: Asterisks $\left({ }^{*},{ }^{* *},{ }^{* * *}\right)$ indicate the significance level $(10 \%, 5 \%, 1 \%)$ of the coefficients. Explanatory variables are lagged by one year. The dependent variable is a dummy variable equal to one when the country is in sovereign default (either on domestic or external debt). 


\section{A simple model linking the debt level, the interest rate and the default probability}

\subsection{Two equations relate the interest rate and the probability of default}

16. If the public debt market is efficient, profitable arbitrage opportunities cannot go unexploited: a relationship between the interest rate and the probability of default exists. Investors are assumed to have a Constant Relative Risk Aversion (CRRA) utility function: $\mathcal{U}(\mathrm{x})=\frac{x^{1-\alpha}}{1-\alpha}$, where $\alpha$ is the degree of relative risk aversion. The utility of a safe asset after one year (left-hand side of the equation) is equal to the utility of a sovereign bond with default risk (right-hand side of the equation):

$$
\begin{aligned}
& u\left(1+r^{*}\right)=\left(1-p_{i, t+1}\right) \mathcal{U}\left(1+r_{i, t}\right)+p_{i, t+1} u\left(\theta\left(1+r_{i, t}\right)\right) \\
& \left(1+r^{*}\right)^{1-\alpha}=\left(1-p_{i, t+1}\right)\left(1+r_{i, t}\right)^{1-\alpha}+p_{i, t+1} \theta^{1-\alpha}\left(1+r_{i, t}\right)^{1-\alpha}
\end{aligned}
$$

where $r^{*}$ denotes the risk-free interest rate, $p_{i, t+1}$ is the default risk in the next year and $\theta$ the assumed recovery rate. This equation reflects the fact that the market risk premium offsets the default risk from the investors' side.

17. The absence of an arbitrage equation and the logistic regression are combined here to investigate the structural links in the long-run steady state in which variables are stable, so that the time subscript is dropped. In this steady state, the effective interest rate in the logistic regression and the market interest rate in the absence of arbitrage opportunity equation are identical. One can thus write the probability of default $p_{i}$ and the interest rate $r_{i}$ as the solution of a system for a given set of structural characteristics and a given debt level:

$$
\left\{\begin{array}{l}
p_{i}=\frac{1}{1+e^{-\left(\beta X_{i}+\beta r_{i} r_{i} \frac{d_{i}}{e} e_{i} \beta_{d} d_{i}\right)}} \\
p_{i}=\frac{\left(1+r_{i}\right)^{1-\alpha}-\left(1+r^{*}\right)^{1-\alpha}}{\left(1+r_{i}\right)^{1-\alpha}\left(1-\theta^{1-\alpha}\right)}
\end{array}\right.
$$

18. This approach aims at capturing a structural interest rate for a given debt level, ignoring shortterm endogenous determinants that could be driven by the structural factors included in the model. The maturity structure in particular is one of those determinants that can be endogenous and hence is ignored here. Indeed, the average maturity decreases when a country is getting closer to the debt limit, because it loses access to long-term bond markets. The debt-to-GDP ratio is stable in the steady state, so the change in this ratio is assumed to be zero in the baseline calculation of debt limits. The importance of this assumption is gauged with an alternative calculation including the change in this ratio observed recently, assuming the model can also reflect a transition that takes a long time from a given debt level to another one (Figure 11, column 4 model).

\subsection{Solutions of the system}

19. This system always has at least one solution and is solved numerically. There are three possible cases. These three cases are illustrated with a virtual country for which the determinants are calculated as cross-country averages, assuming a risk neutral investor $(\alpha=0)$ (Figure 2 ) and a risk free rate of $3 \% .^{2}$ The blue line (logit) provides the structural probability of default as a function of the interest rate and structural determinants. At low levels of debt the curve is relatively flat (Panel A) and shifts to the left as debt increases (Panel B and C). The red line (non-arbitrage opportunity) crosses the blue line at the equilibrium interest rate, which is moderate in Panel A: the probability of default is close to 0 . In an intermediate case (Panel B), there are three solutions, while in Panel $\mathrm{C}$ a single solution is associated with a high default risk.

2. The average recovery rate set at one half in these simulations is not far from historical evidence: Moody's (2008) and Cruces and Trebesch (2011) find that the average recovery rate is about $60 \%$. 
Figure 2. Equilibrium interest rate: Three cases Panel A. Low debt level

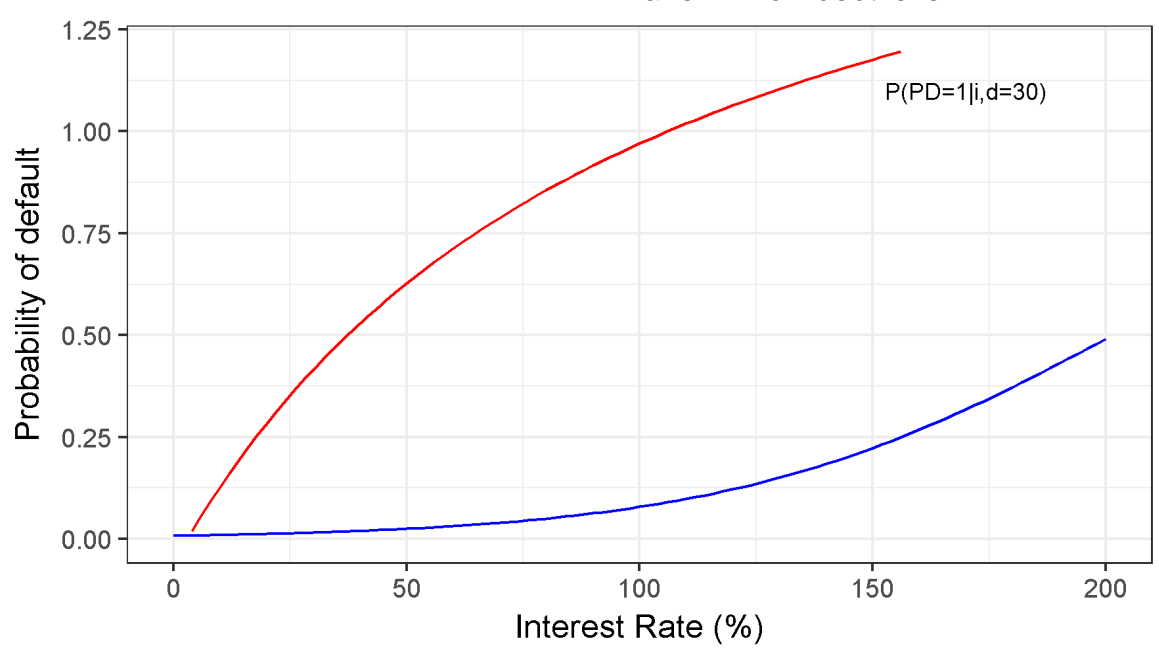

Functions

— Logit

— Non arbitrage opportunity

Panel B. Intermediate debt level

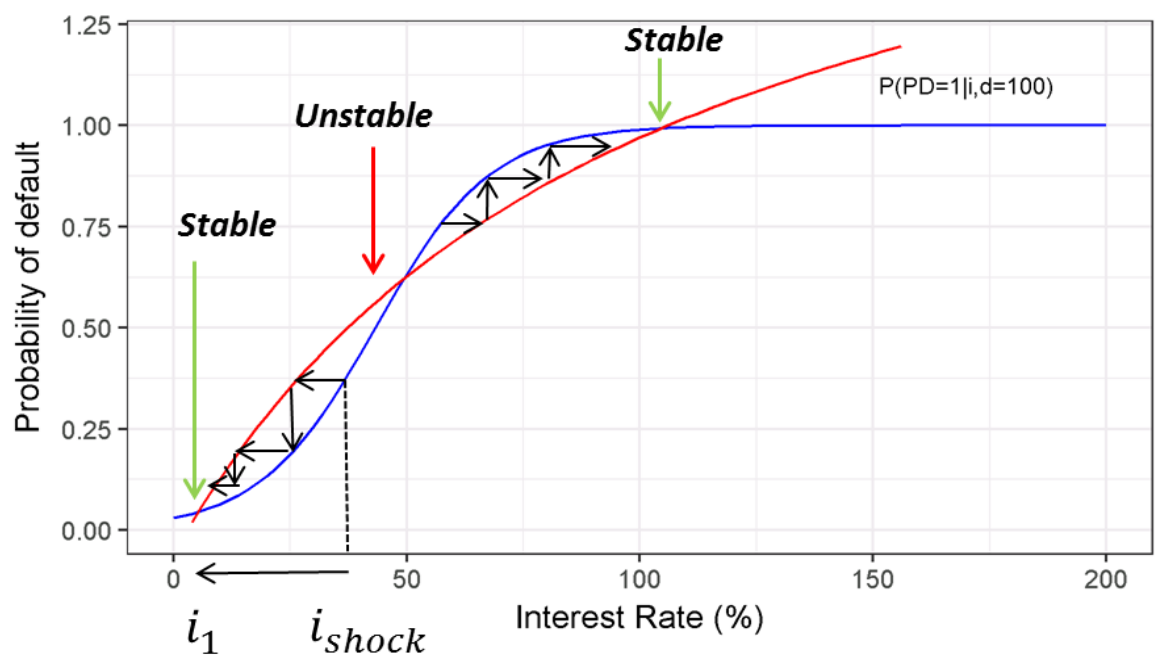

Functions

- Logit

— Non arbitrage opportunity

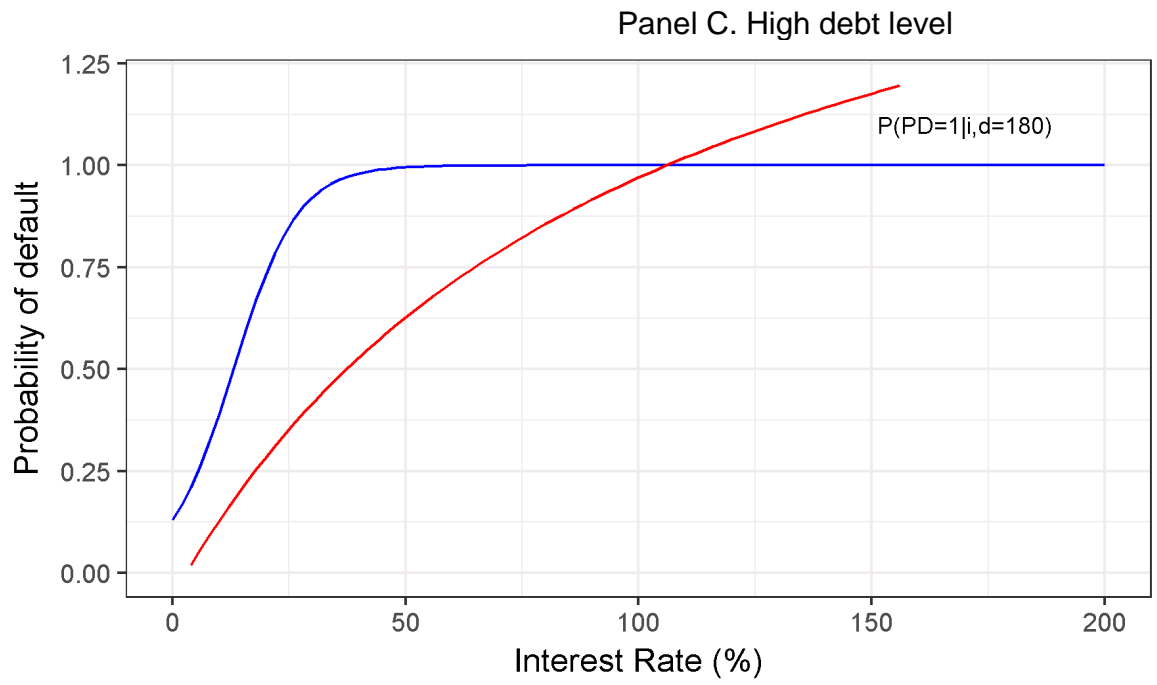

Functions

— Logit

— Non arbitrage opportunity 
20. The system of equations in (1) can be used to assess the stability of the solutions. To assess stability, one can consider the consequence of a large sell-off in the market for sovereign bonds that would be unrelated to any change in the fundamentals. This would create a temporary deviation from the equilibrium. As the price of the bond falls, the interest rate moves from $i_{1}$ to $i_{\text {shock }}$ in Panel B of Figure 2, and the structural default probability can be associated with a lower market interest rate (arrow toward the left). Arbitrage would ensure that the interest rate goes back to the equilibrium. By contrast, the intermediate solution is unstable. The high default probability solution is a stable solution in which a country is almost certain to default every year and pays a high premium (Panel C of Figure 2). This could be regarded as a stylised representation of the serial defaulter case. One could argue that this solution is not consistent with the steady state hypothesis as it cannot match with a stable debt to GDP ratio, and hence it should be excluded from the list of solutions consistent with the initial hypothesis.

21. The debt limit is defined here as the limit case between the multiple equilibria case (Panel B) and the single high-risk premium case (Panel C). In practice, countries with a probability of default close to one may either default or opt for external support such as an IMF programme that can give access to lending below the dissuasive market interest rate. This stylised approach illustrates the importance of conditionality in such programmes, as structural changes can increase the debt limit and hence justify lending at a rate below the market rate. Strictly speaking, with the logistic specification, the default probability can become very close to one, but it cannot become equal to one. This fits with reality as in practice, in a case in which debt is structurally unsustainable one cannot exclude the possibility that financial support is provided.

22. The case with three solutions illustrates the existence of multiple equilibria and the intermediate and unstable equilibrium reveals the risk of a self-fulfilling crisis and interest rate volatility. In such a case, the stable solution with the lowest probability of default is assumed to prevail to compute debt limits. This is the case in particular in the presence of a credible lender of last resort. In the absence of such a lender of last resort, the limit between the low debt level single solution case (Figure 2, Panel A) and the intermediate debt level multiple equilibria solution case (Figure 2, Panel B) could be regarded as the relevant debt limit beyond which the country can face a self-fulfilling crisis.

23. For a given country, the probability of default can be represented as a function of debt, taking into account the effect of debt on the interest rate and holding structural characteristics $X$ constant (Figure 3 , Panel A). The three cases presented in Figure 2 correspond to successive ranges of debt levels in Figure 3. As the feedback effect of the interest rate on debt sustainability is captured in the logistic regression, this provides a non-linear link between the debt level and the interest rate. The default probability is derived in the same way. The curve illustrates the risk of a sudden stop as the probability of default rises sharply if debt level gets close to the debt limit (Figure 3, Panel A). The difference between the stable and the unstable equilibria in the intermediate case can be read as a distance to the self-fulfilling crisis. This distance is decreasing as debt increases (Figure 3, Panel B). 
Figure 3. Debt levels and default probability

Panel A. Probability of default and debt to GDP

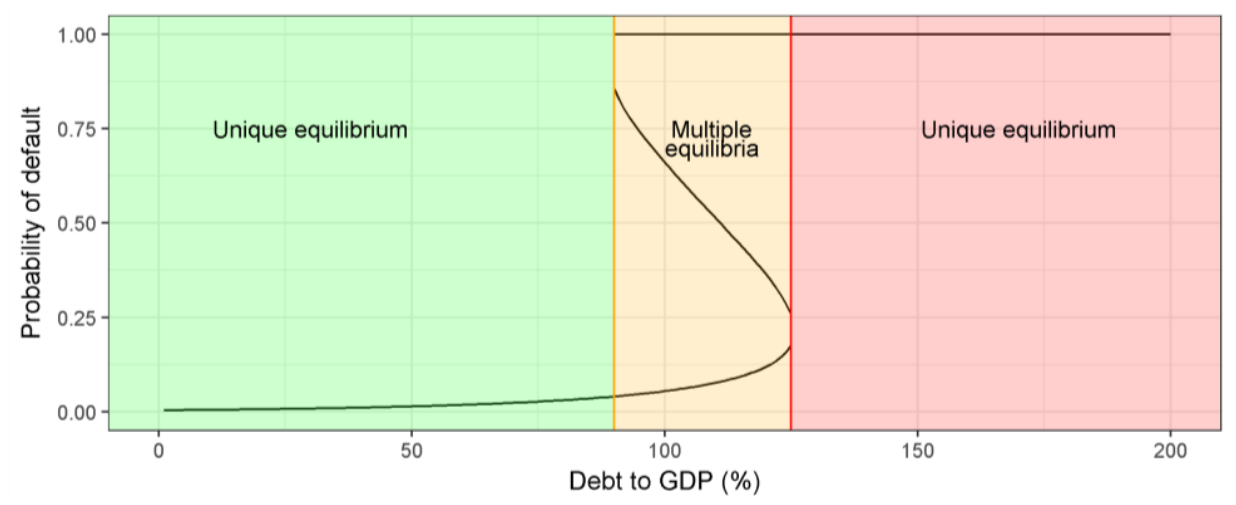

Panel B. Distance to self-fulfilling crisis

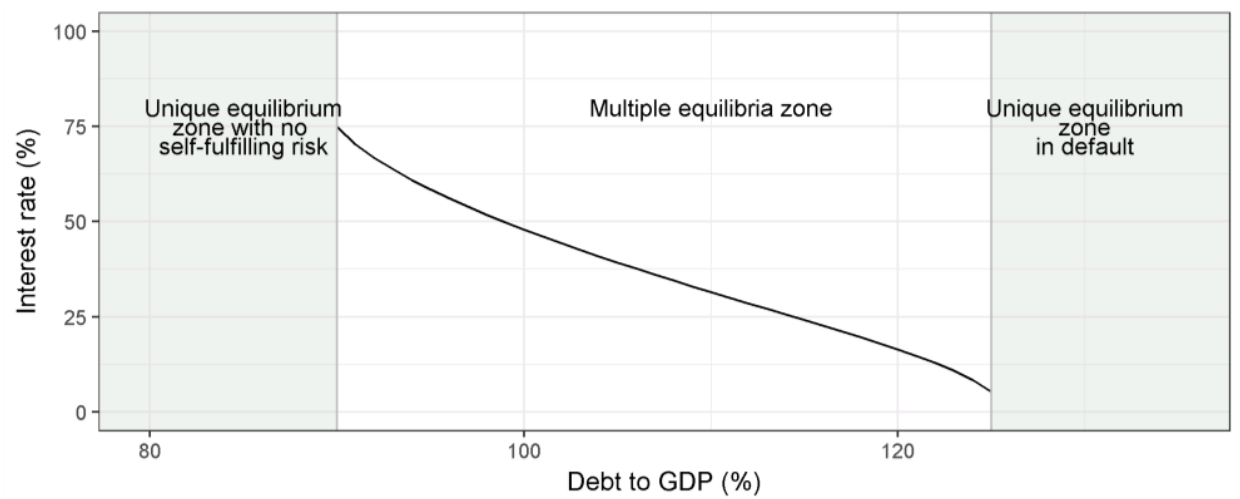

Note: The calibration uses cross-country averages for all inputs. The distance to self-fulfilling crises can be seen as the size of the shock on the equilibrium interest rate that pushes the country from the stable to unstable equilibrium interest rate.

\section{Calculating debt limits}

\subsection{Debt limits and their drivers}

24. Debt limits are calculated for each country (Figure 4). These debt limits vary substantially across countries. They are somewhat below those found by Ghosh et al. (2013) or Fournier and Fall (2017) for advanced countries. This is in line with the debt intolerance phenomenon according to which middleincome countries can suffer difficulties in accessing debt markets at debt levels that are acceptable for high-income countries (Reinhart et al., 2003). The difference between the debt limit and current debt gives an indication on the extent to which countries can increase debt; this can thus be regarded as a distance to debt limit (Figure 5). ${ }^{3}$ These debt limits and fiscal space measures are illustrative as they are derived from a stylised model. In particular, the model assumes that the interest rate is set by the market, while countries under stress may benefit from external support and avoid default (IMF programme, ESM lending).

3. Some may regard this distance as "fiscal space". However, fiscal space is not associated with a consensual definition in the literature (see Botev et al. (2016) for a review). 
ECO/WKP(2018)41

Figure 4. Debt limits and actual debt

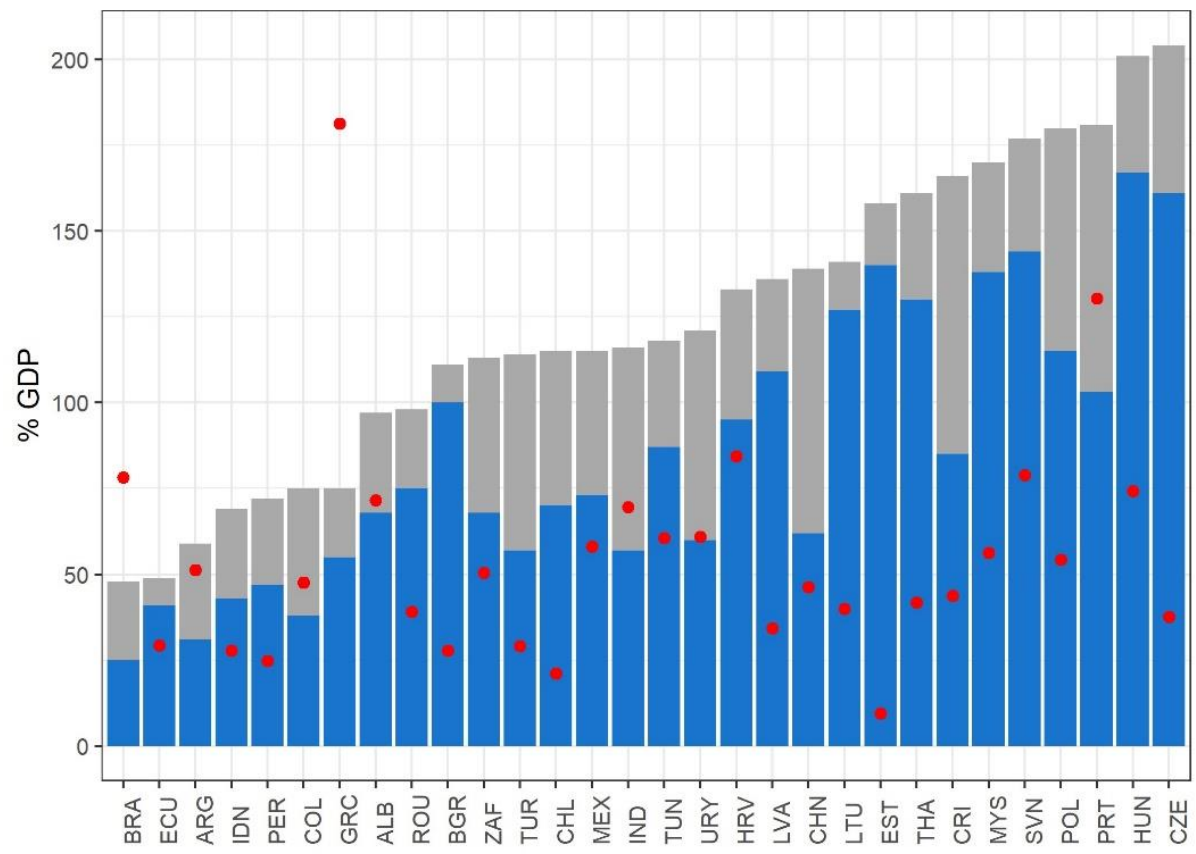

Unique equilibrium zone with no self-fulfilling risk

- Actual debt

Multiple equilibria zone

Note: Actual debt refers to the debt to GDP ratios in 2016. The debt limits are calibrated for a risk-neutral investor $(\alpha=0)$, a recovery rate after default of $50 \%$ and a risk-free interest rate of $3 \%$. External interventions that reduce interest rates are not taken into account in the model.

Figure 5. Distance to the debt limit

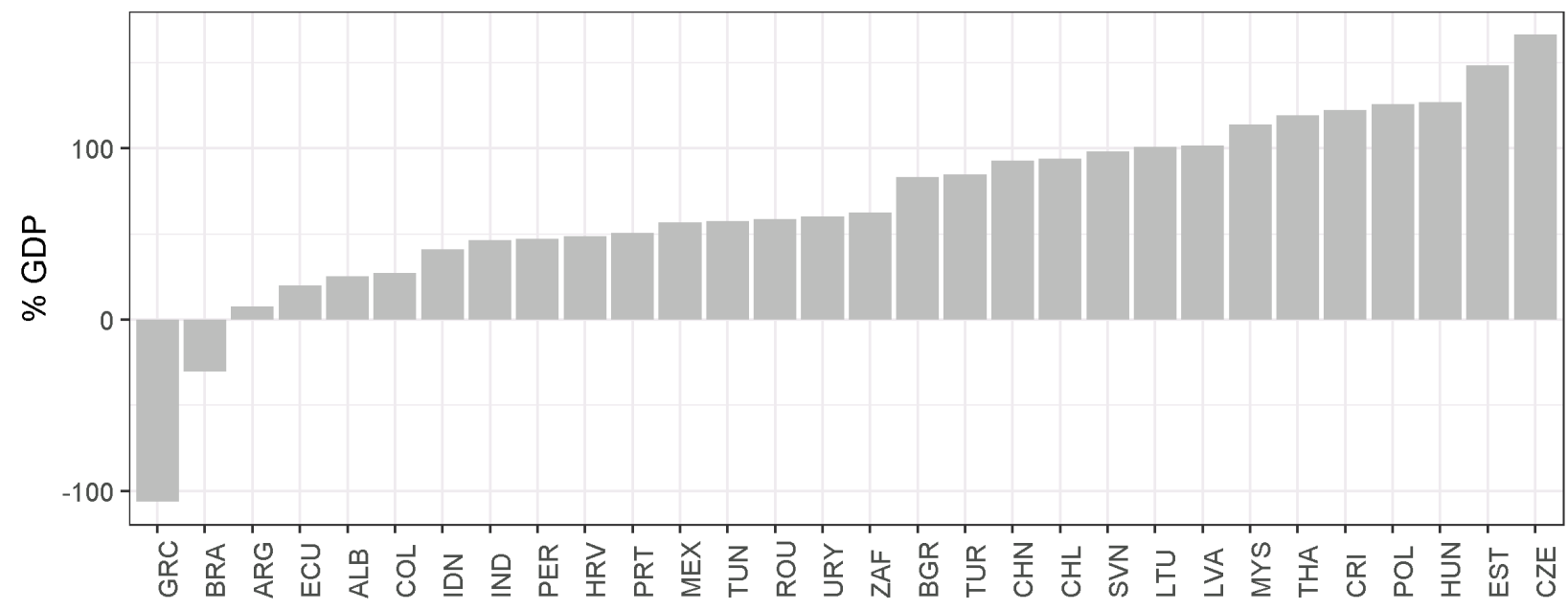

Note: The distance to the debt limit is calculated as the difference between the debt to GDP ratio in 2016 and the estimated debt limit. The debt limits are calibrated for a risk neutral investor $(\alpha=0)$, a recovery rate after default of $50 \%$ and a risk free interest rate of $3 \%$. External interventions that reduce interest rates are not taken into account in the model. 
25. The main drivers of debt limits are the export to GDP ratio and government effectiveness (Figure 6 and Table 2). This is shown by a decomposition of the drivers of debt limits. The debt limit in country $i$ is a function $f$ of $k$ country-specific parameters $x_{i, 1}, \ldots, x_{i, j}, \ldots, x_{i, k}$ and of the arbitrage-free equation parameters $\alpha, r^{*}$ and $\theta$. The contribution of the variable $j$ on the debt limit is defined as the difference between the debt limit and the one that would prevail in a virtual country for which the score of variable $j$ is replaced by the cross-country average:

$$
C_{i, j}=\underbrace{f\left(x_{i, 1}, \ldots, x_{i, j}, \ldots, x_{i, k}, \alpha, r^{*}, \theta\right)}_{\text {debt limit }}-\underbrace{f\left(x_{i, 1}, \ldots, \bar{x}_{j}, \ldots, x_{i, k}, \alpha, r^{*}, \theta\right)}_{\text {debt limit with an average value } \bar{x}_{j}}
$$

26. The relative importance of each determinant can be gauged by an average of absolute contributions (Table 2):

$$
C_{j}=\frac{1}{N} \sum_{i}^{N}\left|f\left(x_{i, 1}, \ldots, x_{i, j}, \ldots, x_{i, k}, \alpha\right)-f\left(x_{i, 1}, \ldots, \bar{x}_{j}, \ldots, x_{i, k}, \alpha\right)\right|
$$

Figure 6. Pseudo contributions to debt limits

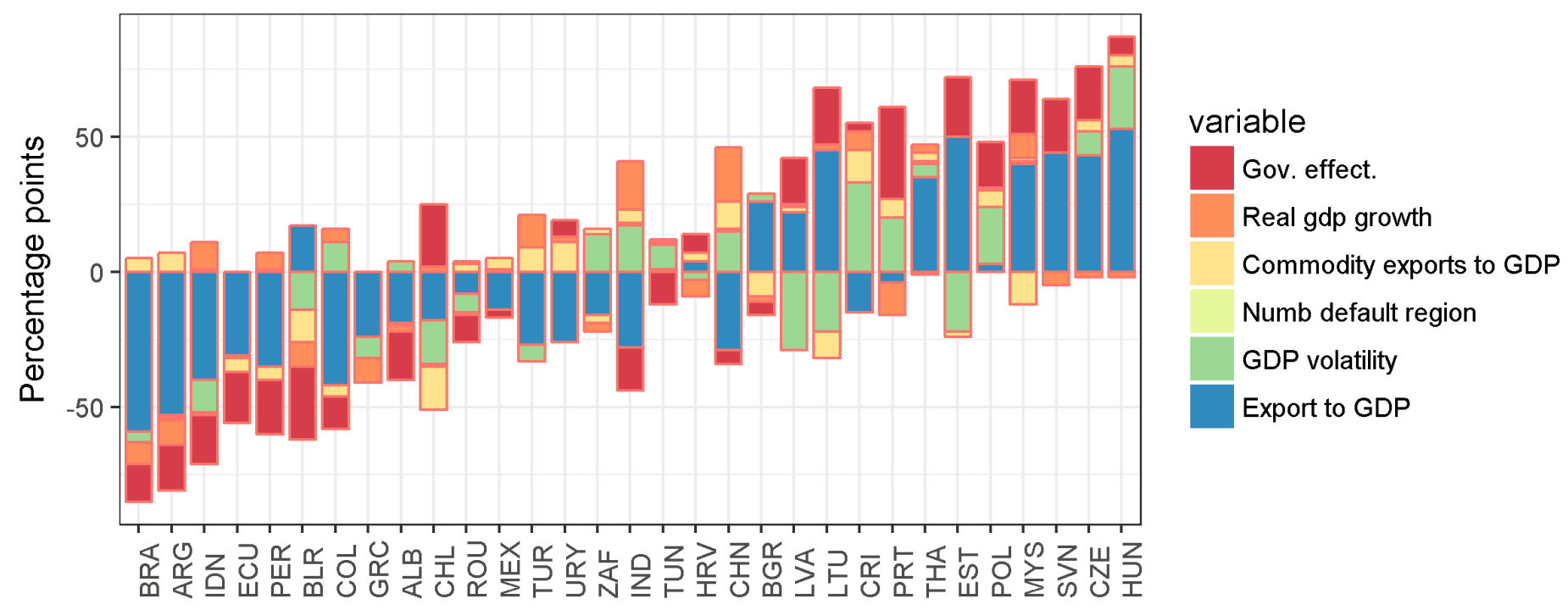

Note: The debt limits are calibrated for a risk neutral investor $(\alpha=0)$, a recovery rate after default of $50 \%$ and a risk free interest rate of $3 \%$. External interventions that reduce interest rates are not taken into account in the model.

The pseudo contributions to the debt limits are calculated so as to show how the debt limit of a country would evolve if each parameter is set at the average level ceteris paribus. For example in the case of Chile the debt limit would be around 25 percentage point lower if the country would have a government effectiveness index equal to the average of middle income countries.

Table 2. Average absolute value of debt limit contributions

\begin{tabular}{lc}
\hline \multicolumn{1}{c}{ Variables } & Average \\
\hline Export ratio & 8.71 \\
Government effectiveness & 4.14 \\
GDP volatility & 3.32 \\
Oil and mining exports to GDP & 1.75 \\
GDP growth & 1.68 \\
Number of defaults in the region & 0.12 \\
\hline
\end{tabular}




\subsection{Sensitivity analysis}

\subsubsection{Debt limits and risk aversion}

27. An increase in investors risk aversion decreases debt limits (Figure 7 and 8). For example, an exogenous tension on financial markets could lead to a crisis of confidence that would increase the risk aversion of investors and make the debt of a country more risky, even the absence of changes to the fundamental determinants. However, changes to risk aversion have only a moderate effect (Figure 9). This is thus likely to be visible only for countries that already had structural weaknesses, so that they were already not that far away from the risk of sovereign default before the rise of risk aversion.

\section{Figure 7. Equilibrium interest rate and risk aversion}

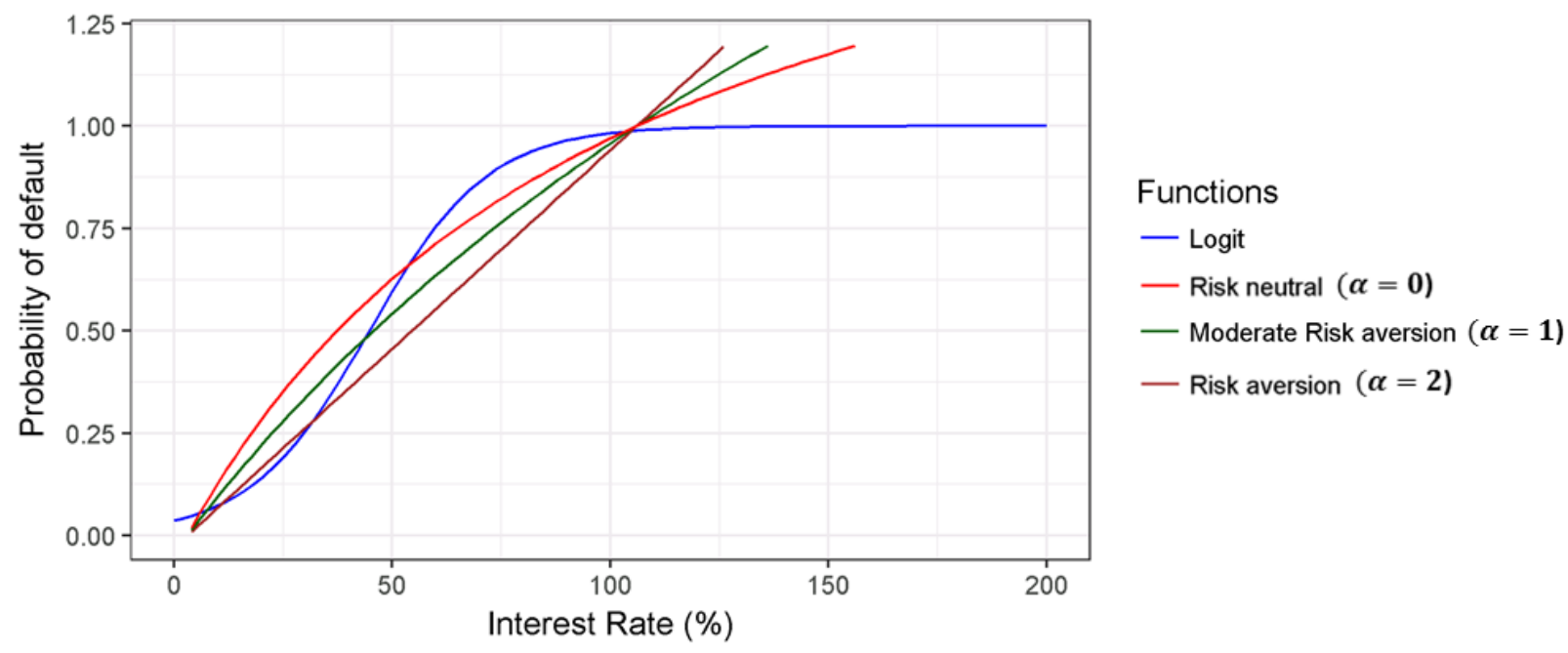

Note: The parameter $\alpha$ refers to the relative risk aversion parameter in the investor's utility function. The logit equation is conditional on a debt to GDP ratio of $85 \%$ for the average country. The calibrated recovery rate after default is set at $50 \%$ and the risk free interest rate is $3 \%$. The range of the risk aversion parameters reflects empirical estimates by Gandelman and Hernández-Murillo (2014).

Figure 8. Probability of default and risk aversion

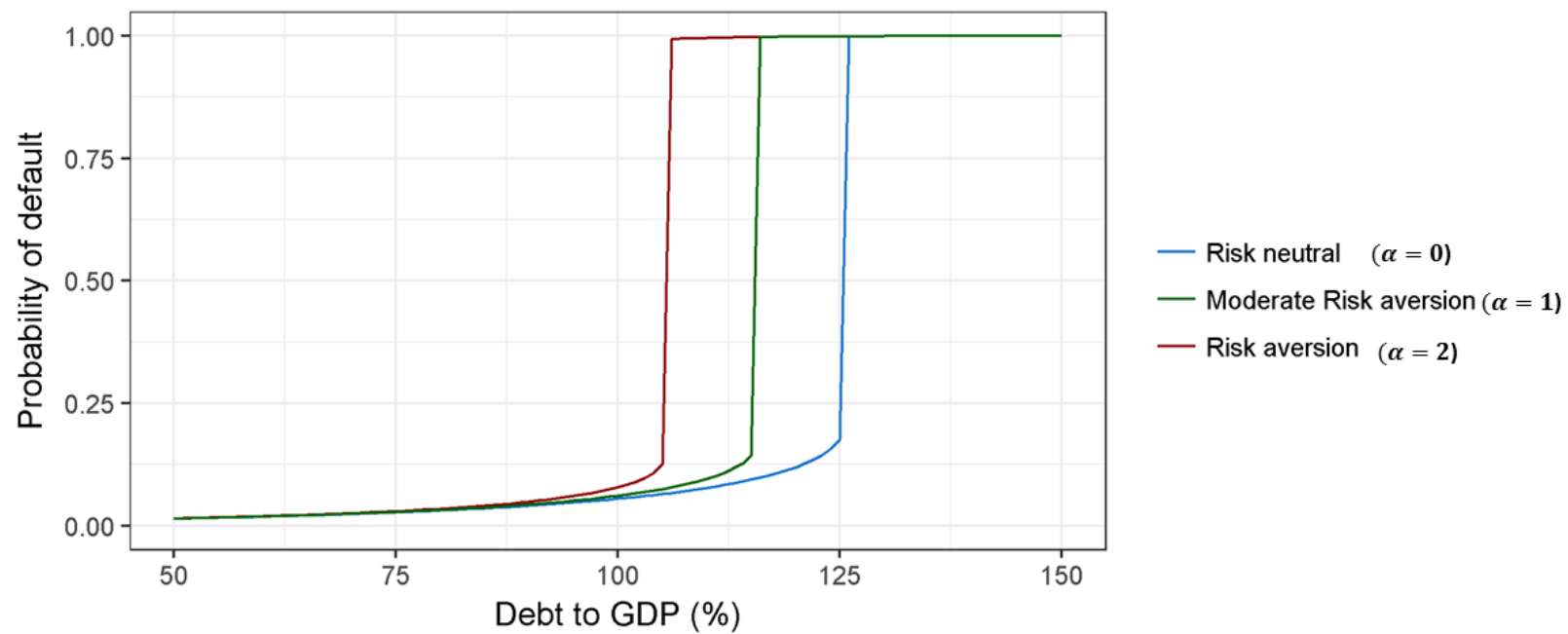

Note: The parameter $\alpha$ refers to the risk aversion parameter in the investor's utility function. The debt limits are calibrated with a recovery rate after default of $50 \%$ and a risk-free interest rate of $3 \%$. In the case of multiple equilibria, the solution with the lowest probability of default is reported. 


\subsubsection{Recovery rate}

28. Given the positive relationship between the risk premium and the loss given default, a higher expected recovery rate reduces interest payments and hence eases the debt burden. This increases the debt limit. For a given set of economic parameters a decrease in the expected cost of default (in terms of and anticipated hair cut in case of renegotiation) increases the debt limit above which the country would switch from a low interest rate equilibrium to a high interest rate equilibrium and thus default.

29. The limit case in which the recovery rate is equal to one provides an illustration of the gains from credibility. In this limit case, the interest rate is always equal to the risk-free interest rate. This corresponds to a country that is expected to always repay its debt. Such a country cannot experience an unstable equilibrium and is not subject to a self-fulfilling crisis. Still, with bad structural determinants implying a high default risk, it could face an insolvency crisis.

\subsubsection{Other sensitivity checks}

30. Figure 9 compares several sensitivity checks. The sensitivity to the recovery rate is the most substantial and illustrates the importance of the self-fulfilling effect of credibility. The sensitivity to government effectiveness is also quite substantial, more so than the sensitivity to risk aversion, the riskfree rate, real GDP growth, the export to GDP ratio or the oil and mining export to GDP ratio. 
Figure 9. Sensitivity of debt limits
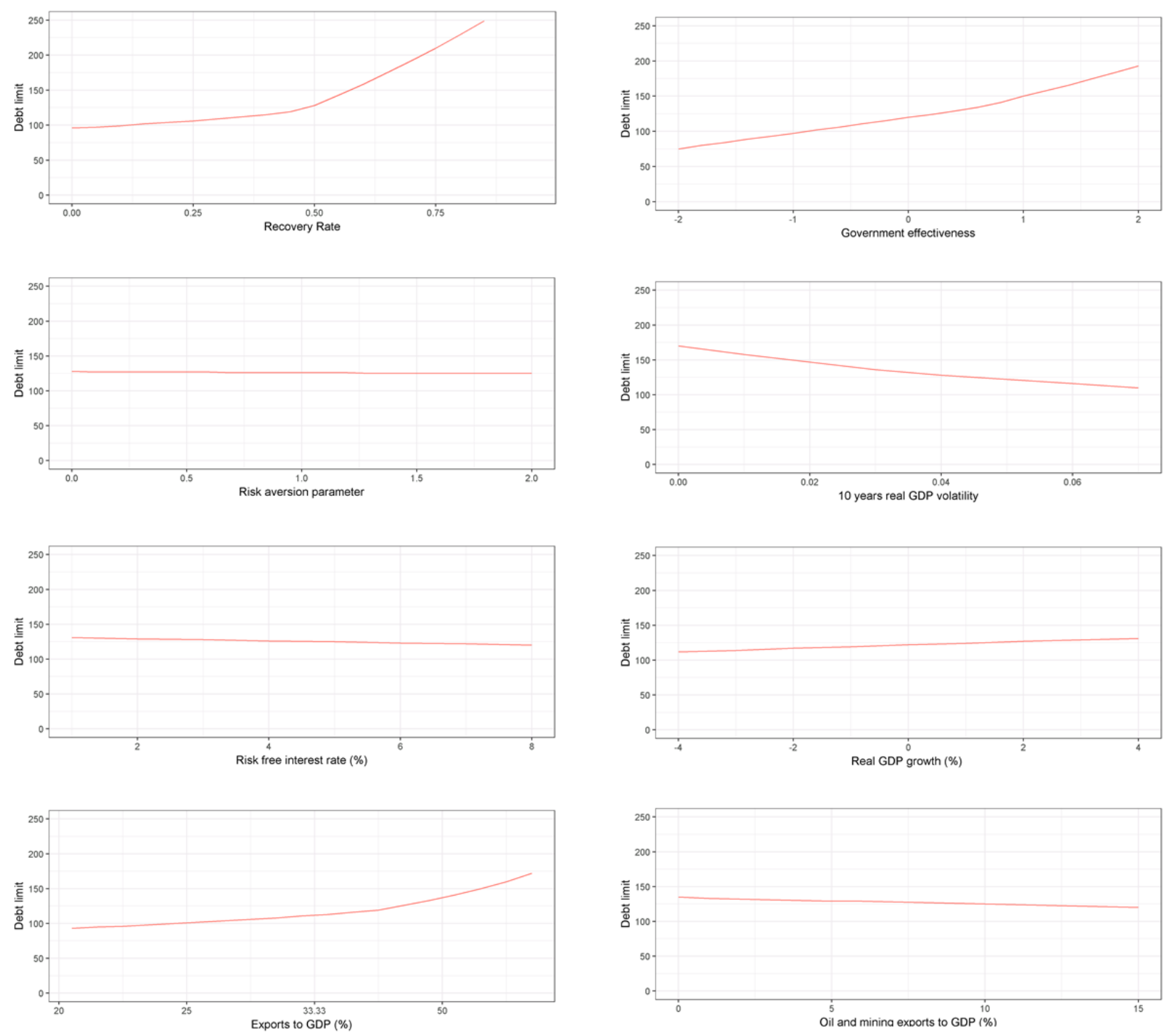

Note: Debt limits are calculated for the average country. For each panel the rest of the variables are constant and the parameters calibrated for a risk neutral investor $(\alpha=0)$, a recovery rate after default of $50 \%$ and a risk-free interest rate of $3 \%$.

\subsubsection{Sensitivity to the choice of the institutional variable}

31. The sensitivity of debt limits to the choice of the institutional variable is investigated with alternative concepts provided by the Worldwide Governance Indicator database (Figure 10 and 11). In most cases, results are similar as these indicators are strongly correlated, but in some specific cases, the assessment can change. As discussed above, practitioners are encouraged to combine such analytical tool with country-specific information to refine the assessment. 
Figure 10. Debt limits and choice of institutional variables

Panel A. Government effectiveness, regulatory quality and rule of law



Panel B. Government effectiveness, control of corruption, voice and accountability and political stability

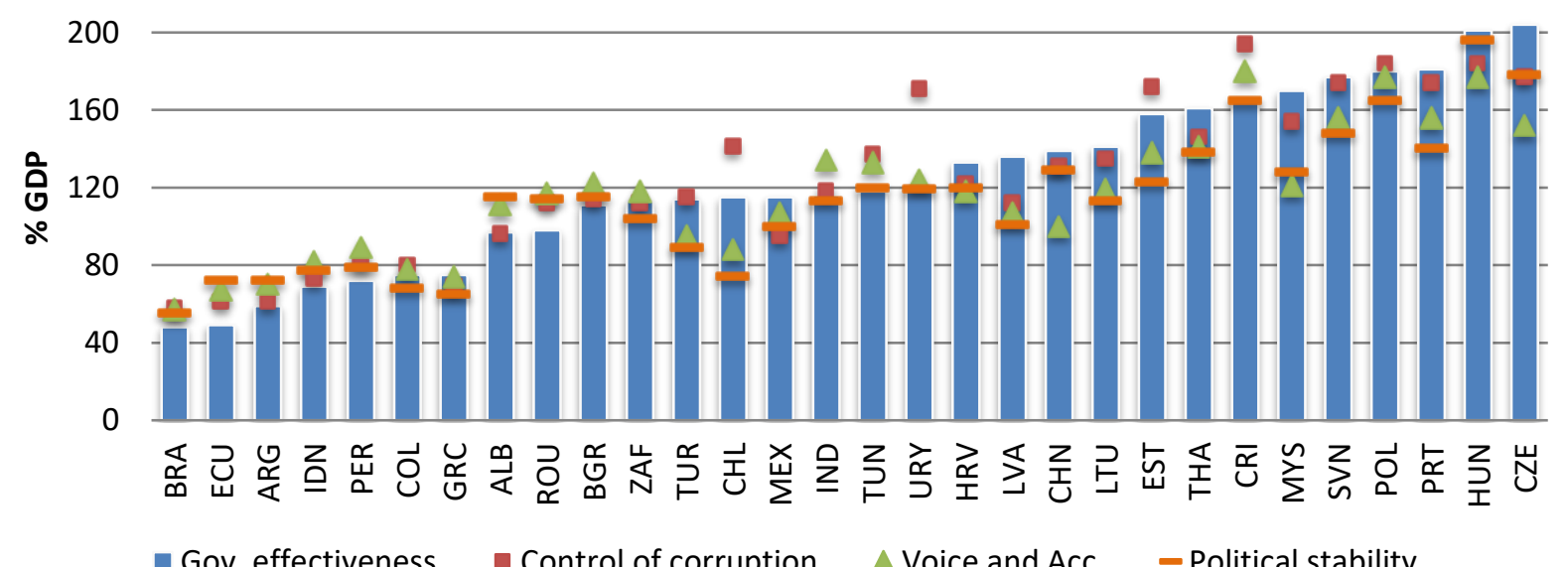

Note: The debt limits are calibrated for a risk neutral investor $(\alpha=0)$, a recovery rate after default of $50 \%$ and a risk-free interest rate of $3 \%$. See Table A1.1 for details of the estimations. 


\subsubsection{Variations of the model specification}

32. The sensitivity of debt limits is fairly moderate in most cases, as illustrated with the example of the specification in column 4 of Table 1 (Figure 11). Still, it can differ substantially in some cases. In particular, if one replaces the interest payment to export ratio by the interest payment to GDP ratio, debt limits are much higher. This reflect the non-significant interest payments to GDP coefficient of column 7 in Table 1 and is not consistent with levels at which sovereign default are observed in the sample. This comparison thus confirms the choice of the interest payment to export ratio to capture the interest payment pressure.

Figure 11. Debt limits depending on model choice



Note: The different debt limits correspond to different specifications of the model and column numbers refer to Table 1.

\subsection{Comparison with credit ratings}

33. Credit rating agencies provide a measure of default risk. In practice, the probability of default derived from the logit estimation is quite well correlated with an average of the ratings of the three principal rating agencies (Figure 12). This is not a surprise as credit rating agencies use information that can be embedded in our model. A noticeable case in which the results differ is the case of Greece in 2010, and hence before the 2012 debt restructuring, suggesting that this restructuring was better anticipated by the model used in this paper than it was by credit rating agencies. 
Figure 12. Estimated probabilities of default and sovereign ratings
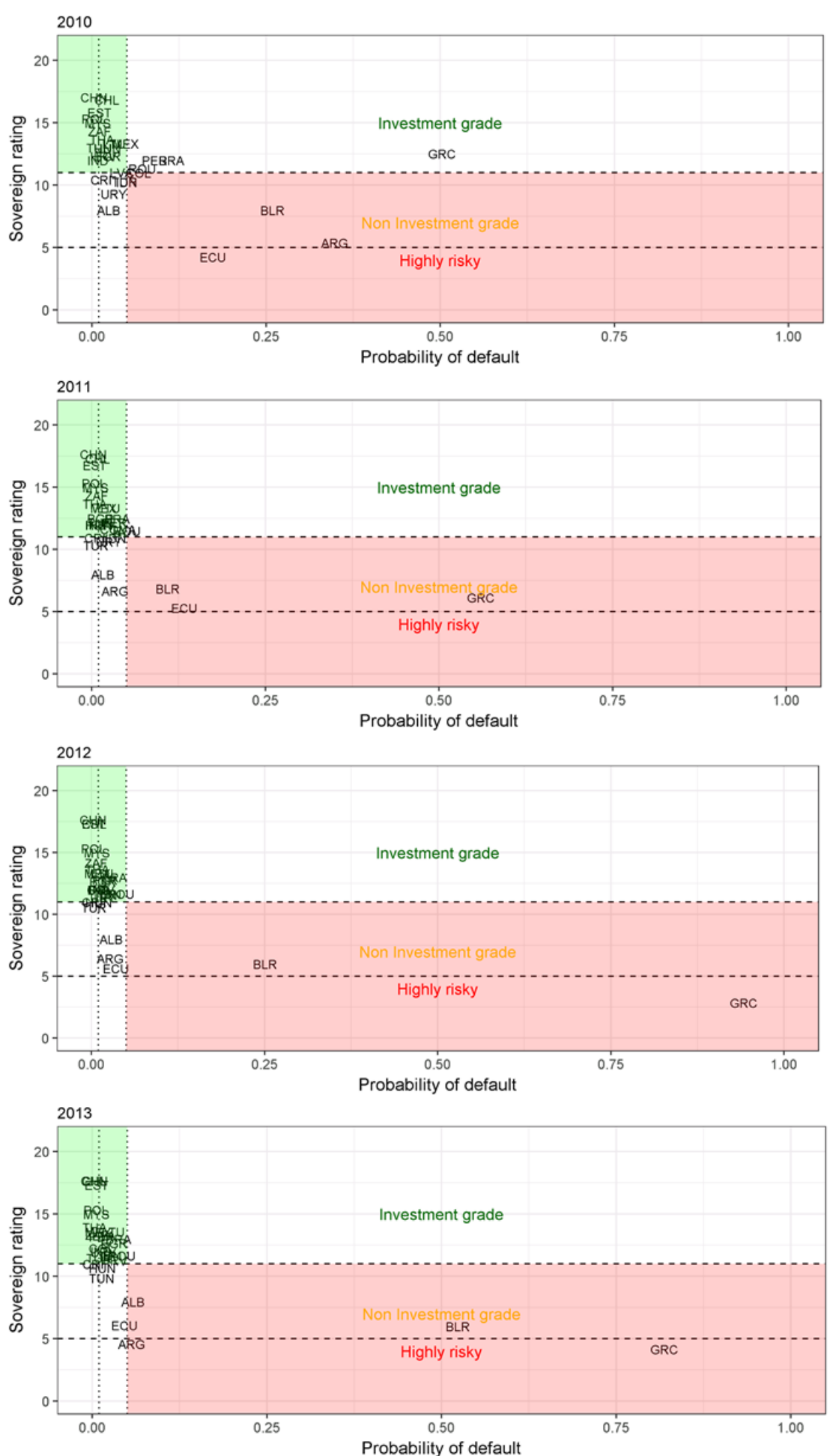

Note: Sovereign ratings come from The Fiscal Space database (The World Bank) and correspond to the average of the ratings of the three principal rating agencies. The probabilities of defaults are computed using the estimations from the logit and correspond to a one-year-ahead forecast. 


\section{APPENDIX}

Table A1.1. Alternative regressions controlling for different institutional variables

\begin{tabular}{|c|c|c|c|c|c|c|}
\hline & $(1)$ & $(2)$ & (3) & $(4)$ & (5) & (6) \\
\hline Gross debt to GDP & $\begin{array}{l}2.19^{* * *} \\
(0.67)\end{array}$ & $\begin{array}{c}1.99^{\star * \star} \\
(0.68)\end{array}$ & $\begin{array}{c}2.69^{* * *} \\
(0.73)\end{array}$ & $\begin{array}{l}2.03^{\star * *} \\
(0.66)\end{array}$ & $\begin{array}{l}1.76^{* * *} \\
(0.63)\end{array}$ & $\begin{array}{l}2.31^{* * *} \\
(0.69)\end{array}$ \\
\hline Real GDP growth & $\begin{array}{c}-13.41^{\star \star \star *} \\
(3.81)\end{array}$ & $\begin{array}{c}-14.79^{\star \star \star} \\
(3.90)\end{array}$ & $\begin{array}{c}-13.76^{\star \star \star} \\
(3.90)\end{array}$ & $\begin{array}{c}13.76^{\star \star \star} \\
(3.80)\end{array}$ & $\begin{array}{c}-14.12^{\star \star \star} \\
(3.82)\end{array}$ & $\begin{array}{c}-14.52^{\star \star \star} \\
(3.90)\end{array}$ \\
\hline $\begin{array}{l}\text { Interest payments } \\
\text { to exports }\end{array}$ & $\begin{array}{l}3.27^{\star \star} \\
(1.30)\end{array}$ & $\begin{array}{l}3.13^{\star \star} \\
(1.38)\end{array}$ & $\begin{array}{l}2.99^{\star \star} \\
(1.32)\end{array}$ & $\begin{array}{c}3.53^{\star * \star} \\
(1.24)\end{array}$ & $\begin{array}{c}3.75^{\star \star \star} \\
(1.25)\end{array}$ & $\begin{array}{l}2.78^{\star \star} \\
(1.32)\end{array}$ \\
\hline $\begin{array}{l}\text { Government } \\
\text { effectiveness }\end{array}$ & $\begin{array}{c}-1.77^{\star \star \star} \\
(0.39)\end{array}$ & & & & & \\
\hline Regulatory quality & & $\begin{array}{c}-1.73^{\star \star \star} \\
(0.34)\end{array}$ & & & & \\
\hline Rule of law & & & $\begin{array}{c}-1.52^{\star \star \star} \\
(0.33)\end{array}$ & & & \\
\hline Political stability & & & & $\begin{array}{c}-0.53^{* *} \\
(0.24)\end{array}$ & & \\
\hline Voice and accountability & & & & & $\begin{array}{l}-0.72^{* *} \\
(0.34)\end{array}$ & \\
\hline Control of corruption & & & & & & $\begin{array}{c}-1.53^{* * *} \\
(0.34)\end{array}$ \\
\hline $\begin{array}{l}\text { Oil and mining exports } \\
\text { to total exports }\end{array}$ & $\begin{array}{l}8.27^{* *} \\
(3.94)\end{array}$ & $\begin{array}{l}8.83^{* *} \\
(3.83)\end{array}$ & $\begin{array}{l}7.50^{*} \\
(4.03)\end{array}$ & $\begin{array}{l}8.07^{\star *} \\
(3.85)\end{array}$ & $\begin{array}{l}6.99^{*} \\
(3.95)\end{array}$ & $\begin{array}{l}7.13^{\star} \\
(4.01)\end{array}$ \\
\hline $\begin{array}{l}\text { Number of defaults } \\
\text { in the region }\end{array}$ & $\begin{array}{l}0.30^{* * *} \\
(0.04)\end{array}$ & $\begin{array}{l}0.33^{* * *} \\
(0.04)\end{array}$ & $\begin{array}{l}0.30^{* * *} \\
(0.04)\end{array}$ & $\begin{array}{l}0.30^{* * *} \\
(0.04)\end{array}$ & $\begin{array}{c}0.32^{* * *} \\
(0.04)\end{array}$ & $\begin{array}{l}0.34^{* * *} \\
(0.04)\end{array}$ \\
\hline $\begin{array}{l}10 \text { year real GDP } \\
\text { volatility }\end{array}$ & $\begin{array}{c}33.59^{* * *} \\
(8.32)\end{array}$ & $\begin{array}{c}34.45^{* * *} \\
(8.49)\end{array}$ & $\begin{array}{c}33.01^{* * *} \\
(8.31)\end{array}$ & $\begin{array}{c}33.98^{* * *} \\
(8.30)\end{array}$ & $\begin{array}{c}33.96^{* * *} \\
(8.34)\end{array}$ & $\begin{array}{c}36.70^{\star * *} \\
(8.46)\end{array}$ \\
\hline Constant & $\begin{array}{c}-6.52^{\star * \star} \\
(0.68)\end{array}$ & $\begin{array}{l}-6.49^{* * *} \\
(0.70)\end{array}$ & $\begin{array}{c}-7.07^{* \star *} \\
(0.74)\end{array}$ & $\begin{array}{c}-6.78^{* \star *} \\
(0.72)\end{array}$ & $\begin{array}{c}-6.40^{* * *} \\
(0.67)\end{array}$ & $\begin{array}{c}-7.09^{* * *} \\
(0.74)\end{array}$ \\
\hline Observations & 531 & 531 & 531 & 531 & 531 & 531 \\
\hline Log Likelihood & -131.27 & -127.98 & -130.51 & -140.99 & -141.08 & -130.61 \\
\hline Akaike Inf. Crit. & 278.54 & 271.95 & 277.02 & 297.99 & 298.17 & 277.23 \\
\hline
\end{tabular}

Note: Asterisks $\left({ }^{*},{ }^{* *},{ }^{* *}\right)$ indicate the significance level $(10 \%, 5 \%, 1 \%)$ of the coefficients. Explanatory variables are lagged by one year. The dependent variable is a dummy variable equal to one when the country is in sovereign default (either on domestic or external debt). 
Table A1.2. Alternative regressions including the size of countries

\begin{tabular}{|c|c|c|c|c|c|}
\hline & (1) & (2) & (3) & (4) & (5) \\
\hline Gross debt to GDP & $\begin{array}{l}2.195^{\star \star \star} \\
(0.674)\end{array}$ & $\begin{array}{l}2.276^{* * *} \\
(0.682)\end{array}$ & $\begin{array}{l}2.448^{\star \star \star} \\
(0.693)\end{array}$ & $\begin{array}{l}2.276^{\star \star \star} \\
(0.682)\end{array}$ & $\begin{array}{l}2.448^{\star * \star} \\
(0.693)\end{array}$ \\
\hline Real GDP growth & $\begin{array}{c}-13.411^{* * *} \\
(3.812)\end{array}$ & $\begin{array}{c}-13.865^{\star * *} \\
(3.870)\end{array}$ & $\begin{array}{c}-13.629^{* * *} \\
(3.863)\end{array}$ & $\begin{array}{c}-13.865^{\star * *} \\
(3.870)\end{array}$ & $\begin{array}{c}-13.629^{\star * *} \\
(3.863)\end{array}$ \\
\hline $\begin{array}{l}\text { Interest payments } \\
\text { to exports }\end{array}$ & $\begin{array}{l}3.267^{\star *} \\
(1.296)\end{array}$ & $\begin{array}{l}3.122^{\star *} \\
(1.317)\end{array}$ & $\begin{array}{l}-2.334 \\
(3.764)\end{array}$ & $\begin{array}{l}3.122^{* *} \\
(1.317)\end{array}$ & $\begin{array}{l}-2.334 \\
(3.764)\end{array}$ \\
\hline $\begin{array}{l}\text { Government } \\
\text { effectiveness }\end{array}$ & $\begin{array}{l}-1.774^{* * \star} \\
(0.393)\end{array}$ & $\begin{array}{c}-1.703^{\star \star *} \\
(0.403)\end{array}$ & $\begin{array}{l}-1.683^{* * *} \\
(0.397)\end{array}$ & $\begin{array}{c}-1.703^{\star \star *} \\
(0.403)\end{array}$ & $\begin{array}{l}-1.683^{* * *} \\
(0.397)\end{array}$ \\
\hline $\begin{array}{l}\text { Oil and mining exports } \\
\text { to GDP }\end{array}$ & $\begin{array}{l}8.271^{* *} \\
(3.937)\end{array}$ & $\begin{array}{l}8.526^{* *} \\
(3.972)\end{array}$ & $\begin{array}{l}9.028^{* *} \\
(3.932)\end{array}$ & $\begin{array}{l}8.526^{\star *} \\
(3.972)\end{array}$ & $\begin{array}{l}9.028^{* *} \\
(3.932)\end{array}$ \\
\hline $\begin{array}{l}\text { Number of defaults } \\
\text { in the region }\end{array}$ & $\begin{array}{l}0.300^{\star \star \star} \\
(0.037)\end{array}$ & $\begin{array}{l}0.310^{\star * \star} \\
(0.040)\end{array}$ & $\begin{array}{l}0.296^{\star \star \star} \\
(0.041)\end{array}$ & $\begin{array}{l}0.310^{\star \star \star} \\
(0.040)\end{array}$ & $\begin{array}{c}0.296^{\star \star \star} \\
(0.041)\end{array}$ \\
\hline $\begin{array}{l}10 \text { year real GDP } \\
\text { volatility }\end{array}$ & $\begin{array}{l}33.589^{* \star *} \\
(8.319)\end{array}$ & $\begin{array}{c}33.857^{\star \star \star} \\
(8.319)\end{array}$ & $\begin{array}{c}34.253^{\star \star \star} \\
(8.446)\end{array}$ & $\begin{array}{l}33.857^{\star \star \star} \\
(8.319)\end{array}$ & $\begin{array}{c}34.253^{\star * \star} \\
(8.446)\end{array}$ \\
\hline $\begin{array}{l}\text { Interest payments to exports } \\
{ }^{*} \text { log of population }\end{array}$ & & & $\begin{array}{c}1.723 \\
(1.117)\end{array}$ & & \\
\hline Log of population & & $\begin{array}{c}0.116 \\
(0.133)\end{array}$ & $\begin{array}{l}-0.202 \\
(0.248)\end{array}$ & & \\
\hline $\begin{array}{l}\text { Interest payments to exports } \\
\text { * log GDP in PPP }\end{array}$ & & & & & $\begin{array}{c}1.723 \\
(1.117)\end{array}$ \\
\hline Log GDP in PPP & & & & $\begin{array}{c}0.116 \\
(0.133)\end{array}$ & $\begin{array}{l}-0.202 \\
(0.248)\end{array}$ \\
\hline Constant & $\begin{array}{c}-6.516^{* \star *} \\
(0.683)\end{array}$ & $\begin{array}{c}-7.011^{* \star *} \\
(0.903)\end{array}$ & $\begin{array}{c}-6.048^{\star * *} \\
(1.067)\end{array}$ & $\begin{array}{c}-7.011^{* * *} \\
(0.903)\end{array}$ & $\begin{array}{l}-6.048^{* * *} \\
(1.067)\end{array}$ \\
\hline Observations & 531 & 531 & 531 & 531 & 531 \\
\hline Log Likelihood & -131.271 & -130.885 & -129.656 & -130.885 & -129.656 \\
\hline Akaike Inf. Crit. & 278.542 & 279.770 & 279.311 & 279.770 & 279.311 \\
\hline
\end{tabular}

Note: Asterisks $\left({ }^{*},{ }^{* *},{ }^{* * *}\right)$ indicate the significance level $(10 \%, 5 \%, 1 \%)$ of the coefficients. Explanatory variables are lagged by one year. The dependent variable is a dummy variable equal to one when the country is in sovereign default (either on domestic or external debt). 
Table A1.3. Alternative regressions using different interest payment concepts

\begin{tabular}{|c|c|c|c|c|c|}
\hline & (1) & (2) & (3) & (4) & (5) \\
\hline Gross debt to GDP & $\begin{array}{l}2.195^{\star \star \star} \\
(0.674)\end{array}$ & $\begin{array}{l}2.388^{* * *} \\
(0.706)\end{array}$ & $\begin{array}{l}2.442^{\star \star *} \\
(0.672)\end{array}$ & $\begin{array}{l}2.545^{\star \star \star} \\
(0.661)\end{array}$ & $\begin{array}{l}6.196^{\star *} \\
(2.626)\end{array}$ \\
\hline Real GDP growth & $\begin{array}{c}-13.411^{* * *} \\
(3.812)\end{array}$ & $\begin{array}{c}-15.163^{\star * *} \\
(3.426)\end{array}$ & $\begin{array}{c}-15.274^{\star * *} \\
(3.681)\end{array}$ & $\begin{array}{c}-15.548^{* * *} \\
(3.425)\end{array}$ & $\begin{array}{c}-36.256^{\star * *} \\
(13.623)\end{array}$ \\
\hline $\begin{array}{l}\text { Interest payments } \\
\text { to exports }\end{array}$ & $\begin{array}{l}3.267^{* *} \\
(1.296)\end{array}$ & & & & \\
\hline $\begin{array}{l}\text { Interest payments } \\
\text { to GDP }\end{array}$ & & $\begin{array}{c}1.726 \\
(6.895)\end{array}$ & & & \\
\hline $\begin{array}{l}\text { Total debt service } \\
\text { to exports }\end{array}$ & & & $\begin{array}{c}0.062 \\
(0.340)\end{array}$ & & \\
\hline $\begin{array}{l}\text { Total debt service } \\
\text { to GDP }\end{array}$ & & & & $\begin{array}{l}-0.552 \\
(1.651)\end{array}$ & \\
\hline Effective interest rate & & & & & $\begin{array}{l}-27.475 \\
(19.319)\end{array}$ \\
\hline $\begin{array}{l}\text { Government } \\
\text { effectiveness }\end{array}$ & $\begin{array}{l}-1.774^{* * *} \\
(0.393)\end{array}$ & $\begin{array}{l}-1.385^{\star * \star} \\
(0.345)\end{array}$ & $\begin{array}{c}-1.835^{\star * *} \\
(0.398)\end{array}$ & $\begin{array}{l}-1.387^{\star * *} \\
(0.346)\end{array}$ & $\begin{array}{l}-4.065^{\star} \\
(2.111)\end{array}$ \\
\hline $\begin{array}{l}\text { Oil and mining exports } \\
\text { to GDP }\end{array}$ & $\begin{array}{l}8.271^{* *} \\
(3.937)\end{array}$ & $\begin{array}{c}5.789 \\
(3.649)\end{array}$ & $\begin{array}{l}7.106^{*} \\
(3.920)\end{array}$ & $\begin{array}{l}5.973^{*} \\
(3.585)\end{array}$ & $\begin{array}{c}15.674 \\
(15.987)\end{array}$ \\
\hline $\begin{array}{l}\text { Number of defaults } \\
\text { in the region }\end{array}$ & $\begin{array}{l}0.300^{* \star *} \\
(0.037)\end{array}$ & $\begin{array}{l}0.286^{* * *} \\
(0.034)\end{array}$ & $\begin{array}{l}0.331^{* * *} \\
(0.037)\end{array}$ & $\begin{array}{l}0.285^{\star \star \star} \\
(0.034)\end{array}$ & $\begin{array}{l}-0.084 \\
(0.245)\end{array}$ \\
\hline $\begin{array}{l}10 \text { year real GDP } \\
\text { volatility }\end{array}$ & $\begin{array}{l}33.589^{\star * \star} \\
(8.319)\end{array}$ & $\begin{array}{l}38.120^{* * *} \\
(7.935)\end{array}$ & $\begin{array}{l}35.087 \\
(8.422)\end{array}$ & $\begin{array}{l}38.178^{* * *} \\
(7.931)\end{array}$ & $\begin{array}{c}108.038^{* * *} \\
(32.723)\end{array}$ \\
\hline Constant & $\begin{array}{c}-6.516^{\star \star \star} \\
(0.683)\end{array}$ & $\begin{array}{c}-5.900^{\star \star \star} \\
(0.601)\end{array}$ & $\begin{array}{l}-6.257^{\star * \star} \\
(0.667)\end{array}$ & $\begin{array}{c}-5.854^{\star * \star} \\
(0.613)\end{array}$ & $\begin{array}{c}-10.550^{* \star *} \\
(3.393)\end{array}$ \\
\hline Observations & 531 & 553 & 531 & 553 & 287 \\
\hline Log Likelihood & -131.271 & -154.840 & -134.290 & -154.813 & -17.665 \\
\hline Akaike Inf. Crit. & 278.542 & 325.680 & 284.580 & 325.627 & 51.331 \\
\hline
\end{tabular}

Note: Asterisks $\left({ }^{*},{ }^{* *},{ }^{* * *}\right)$ indicate the significance level $(10 \%, 5 \%, 1 \%)$ of the coefficients. Explanatory variables are lagged by one year. The dependent variable is a dummy variable equal to one when the country is in sovereign default (either on domestic or external debt). Total debt service includes payment of both interest and principal. 
Table A1.4. Alternative regressions controlling for exchange rate regimes

\begin{tabular}{|c|c|c|c|c|}
\hline & (1) & (2) & (3) & (4) \\
\hline Gross debt to GDP & $\begin{array}{l}2.195^{\star \star \star} \\
(0.674)\end{array}$ & $\begin{array}{l}2.260^{* * *} \\
(0.695)\end{array}$ & $\begin{array}{l}2.260^{* * *} \\
(0.695)\end{array}$ & $\begin{array}{l}2.142^{* \star *} \\
(0.676)\end{array}$ \\
\hline Real GDP growth & $\begin{array}{l}-13.411^{* * *} \\
(3.812)\end{array}$ & $\begin{array}{l}-12.343^{* \star \star} \\
(3.899)\end{array}$ & $\begin{array}{l}-12.343^{* * \star} \\
(3.899)\end{array}$ & $\begin{array}{l}-12.376^{\star \star \star} \\
(3.924)\end{array}$ \\
\hline $\begin{array}{l}\text { Interest payments } \\
\text { to exports }\end{array}$ & $\begin{array}{l}3.267^{\star *} \\
(1.296)\end{array}$ & $\begin{array}{l}4.440^{* * *} \\
(1.529)\end{array}$ & $\begin{array}{c}4.440^{* * *} \\
(1.529)\end{array}$ & $\begin{array}{l}3.239^{* *} \\
(1.315)\end{array}$ \\
\hline $\begin{array}{l}\text { Government } \\
\text { effectiveness }\end{array}$ & $\begin{array}{l}-1.774^{\star \star *} \\
(0.393)\end{array}$ & $\begin{array}{l}-1.710^{* * *} \\
(0.399)\end{array}$ & $\begin{array}{l}-1.710^{* * *} \\
(0.399)\end{array}$ & $\begin{array}{l}-1.707^{* * *} \\
(0.389)\end{array}$ \\
\hline $\begin{array}{l}\text { Oil and mining exports } \\
\text { to GDP }\end{array}$ & $\begin{array}{l}8.271^{\star *} \\
(3.937)\end{array}$ & $\begin{array}{c}10.044^{\star *} \\
(4.174)\end{array}$ & $\begin{array}{c}10.044^{* *} \\
(4.174)\end{array}$ & $\begin{array}{l}9.254^{\star *} \\
(3.915)\end{array}$ \\
\hline $\begin{array}{l}\text { Number of defaults } \\
\text { in the region }\end{array}$ & $\begin{array}{l}0.300^{\star \star \star} \\
(0.037)\end{array}$ & $\begin{array}{l}0.281^{* * *} \\
(0.039)\end{array}$ & $\begin{array}{l}0.281^{* * *} \\
(0.039)\end{array}$ & $\begin{array}{l}0.286^{* * *} \\
(0.038)\end{array}$ \\
\hline $\begin{array}{l}10 \text { year real GDP } \\
\text { Volatility }\end{array}$ & $\begin{array}{c}33.589^{* * *} \\
(8.319)\end{array}$ & $\begin{array}{l}29.430^{\star \star \star} \\
(8.482)\end{array}$ & $\begin{array}{c}29.430^{\star * *} \\
(8.482)\end{array}$ & $\begin{array}{c}35.299^{\star * *} \\
(8.467)\end{array}$ \\
\hline $\begin{array}{l}\text { Dummy for floating } \\
\text { exchange rate }\end{array}$ & & $\begin{array}{c}0.212 \\
(0.433)\end{array}$ & & \\
\hline $\begin{array}{l}\text { Dummy for pegged } \\
\text { exchange rate }\end{array}$ & & & $\begin{array}{l}-0.212 \\
(0.433)\end{array}$ & \\
\hline $\begin{array}{l}\text { Change in the exchange rate } \\
\text { (increase = depreciation) }\end{array}$ & & & & $\begin{array}{l}0.172^{*} \\
(0.095)\end{array}$ \\
\hline Constant & $\begin{array}{c}-6.516^{\star \star \star} \\
(0.683)\end{array}$ & $\begin{array}{c}-6.685^{\star * *} \\
(0.815)\end{array}$ & $\begin{array}{c}-6.473^{* * *} \\
(0.707)\end{array}$ & $\begin{array}{c}-6.661^{* * *} \\
(0.695)\end{array}$ \\
\hline Observations & 531 & 489 & 489 & 531 \\
\hline Log Likelihood & -131.271 & -124.801 & -124.801 & -128.856 \\
\hline Akaike Inf. Crit. & 278.542 & 267.602 & 267.602 & 275.713 \\
\hline
\end{tabular}

Note: Asterisks $\left({ }^{*},{ }^{* *},{ }^{* * *}\right)$ indicate the significance level $(10 \%, 5 \%, 1 \%)$ of the coefficients. Explanatory variables are lagged by one year. The dependent variable is a dummy variable equal to one when the country is in sovereign default (either on domestic or external debt). 
Table A1.5. Alternative regressions including the long-term GDP growth rate

\begin{tabular}{|c|c|c|c|c|c|}
\hline & (1) & (2) & (3) & (4) & (5) \\
\hline Gross debt to GDP & $\begin{array}{l}2.195^{\star \star \star} \\
(0.674)\end{array}$ & $\begin{array}{l}2.276^{\star \star \star} \\
(0.712)\end{array}$ & $\begin{array}{l}2.721^{* \star *} \\
(0.807)\end{array}$ & $\begin{array}{c}2.687^{* \star \star} \\
(0.826)\end{array}$ & $\begin{array}{l}3.082^{\star \star *} \\
(0.887)\end{array}$ \\
\hline Real GDP growth & $\begin{array}{c}-13.411^{\star * \star} \\
(3.812)\end{array}$ & & & & \\
\hline $\begin{array}{l}2 \text { year average } \\
\text { real GDP growth }\end{array}$ & & $\begin{array}{l}-18.767^{* * *} \\
(5.008)\end{array}$ & & & \\
\hline $\begin{array}{l}3 \text { year average } \\
\text { real GDP growth }\end{array}$ & & & $\begin{array}{c}-17.631^{* \star *} \\
(6.152)\end{array}$ & & \\
\hline $\begin{array}{l}4 \text { year average } \\
\text { real GDP growth }\end{array}$ & & & & $\begin{array}{c}-17.372^{* *} \\
(7.129)\end{array}$ & \\
\hline $\begin{array}{l}5 \text { year average } \\
\text { real GDP growth }\end{array}$ & & & & & $\begin{array}{l}-13.101 \\
(8.465)\end{array}$ \\
\hline $\begin{array}{l}\text { Interest payments } \\
\text { to exports }\end{array}$ & $\begin{array}{l}3.267^{\star *} \\
(1.296)\end{array}$ & $\begin{array}{l}2.956^{\star *} \\
(1.351)\end{array}$ & $\begin{array}{c}1.782 \\
(1.563)\end{array}$ & $\begin{array}{c}1.561 \\
(1.645)\end{array}$ & $\begin{array}{c}1.355 \\
(1.704)\end{array}$ \\
\hline $\begin{array}{l}\text { Government } \\
\text { effectiveness }\end{array}$ & $\begin{array}{c}-1.774^{* * *} \\
(0.393)\end{array}$ & $\begin{array}{c}-1.753^{\star \star \star} \\
(0.407)\end{array}$ & $\begin{array}{l}-1.942^{\star \star *} \\
(0.450)\end{array}$ & $\begin{array}{c}-1.928^{\star * *} \\
(0.458)\end{array}$ & $\begin{array}{c}-2.131^{* * *} \\
(0.485)\end{array}$ \\
\hline $\begin{array}{l}\text { Oil and mining exports } \\
\text { to GDP }\end{array}$ & $\begin{array}{l}8.271^{* *} \\
(3.937)\end{array}$ & $\begin{array}{l}8.305^{\star *} \\
(4.197)\end{array}$ & $\begin{array}{l}7.526^{*} \\
(4.475)\end{array}$ & $\begin{array}{c}7.185 \\
(4.640)\end{array}$ & $\begin{array}{c}6.080 \\
(4.820)\end{array}$ \\
\hline $\begin{array}{l}\text { Number of defaults } \\
\text { in the region }\end{array}$ & $\begin{array}{l}0.300^{* * *} \\
(0.037)\end{array}$ & $\begin{array}{l}0.321^{* * *} \\
(0.039)\end{array}$ & $\begin{array}{l}0.312^{\star \star \star} \\
(0.040)\end{array}$ & $\begin{array}{l}0.298^{* * *} \\
(0.039)\end{array}$ & $\begin{array}{l}0.291^{\star * *} \\
(0.040)\end{array}$ \\
\hline $\begin{array}{l}10 \text { year real GDP } \\
\text { Volatility }\end{array}$ & $\begin{array}{c}33.589^{* * *} \\
(8.319)\end{array}$ & $\begin{array}{c}34.799^{* * *} \\
(8.759)\end{array}$ & $\begin{array}{l}35.485^{* * *} \\
(9.160)\end{array}$ & $\begin{array}{l}34.512^{* * *} \\
(9.194)\end{array}$ & $\begin{array}{l}33.907^{* * *} \\
(9.258)\end{array}$ \\
\hline Constant & $\begin{array}{c}-6.516^{\star \star \star} \\
(0.683)\end{array}$ & $\begin{array}{c}-6.557^{\star \star \star} \\
(0.733)\end{array}$ & $\begin{array}{l}-6.719^{\star \star \star} \\
(0.799)\end{array}$ & $\begin{array}{c}-6.529^{* \star *} \\
(0.810)\end{array}$ & $\begin{array}{c}-6.769^{* * *} \\
(0.885)\end{array}$ \\
\hline Observations & 531 & 516 & 499 & 483 & 467 \\
\hline Log Likelihood & -131.271 & -120.087 & -111.841 & -109.985 & -104.675 \\
\hline Akaike Inf. Crit. & 278.542 & 256.174 & 239.683 & 235.969 & 225.350 \\
\hline
\end{tabular}

Note: Asterisks $\left({ }^{*},{ }^{* *},{ }^{* * *}\right)$ indicate the significance level $(10 \%, 5 \%, 1 \%)$ of the coefficients. Explanatory variables are lagged by one year. The dependent variable is a dummy variable equal to one when the country is in sovereign default (either on domestic or external debt). 
Table A1.6. Alternative regressions including fiscal rules

\begin{tabular}{|c|c|c|c|}
\hline & $(1)$ & (2) & (3) \\
\hline Gross debt to GDP & $\begin{array}{l}2.133^{* * *} \\
(0.677)\end{array}$ & $\begin{array}{l}2.474^{* \star *} \\
(0.702)\end{array}$ & $\begin{array}{l}2.375^{\star \star \star} \\
(0.691)\end{array}$ \\
\hline Dummy for debt rule & & $\begin{array}{l}-0.239^{* *} \\
(1.812)\end{array}$ & $\begin{array}{l}-1.651^{\star *} \\
(0.798)\end{array}$ \\
\hline Real GDP growth & $\begin{array}{l}-13.988^{* * *} \\
(3.879)\end{array}$ & $\begin{array}{l}-12.768^{* * *} \\
(3.798)\end{array}$ & $\begin{array}{l}-12.914^{\star * *} \\
(3.801)\end{array}$ \\
\hline $\begin{array}{l}\text { Interest payments } \\
\text { to exports }\end{array}$ & $\begin{array}{l}3.226^{* *} \\
(1.312)\end{array}$ & $\begin{array}{c}3.791^{* * *} \\
(1.420)\end{array}$ & $\begin{array}{l}3.514^{\star * *} \\
(1.342)\end{array}$ \\
\hline $\begin{array}{l}\text { Government } \\
\text { effectiveness }\end{array}$ & $\begin{array}{l}-1.719^{* * *} \\
(0.390)\end{array}$ & $\begin{array}{l}-1.857^{* * *} \\
(0.414)\end{array}$ & $\begin{array}{c}-1.898^{* * *} \\
(0.410)\end{array}$ \\
\hline $\begin{array}{l}\text { Oil and mining exports } \\
\text { to GDP }\end{array}$ & $\begin{array}{c}6.467 \\
(4.168)\end{array}$ & $\begin{array}{l}8.892^{* *} \\
(4.252)\end{array}$ & $\begin{array}{l}9.622^{* \star} \\
(4.126)\end{array}$ \\
\hline $\begin{array}{l}\text { Number of defaults } \\
\text { in the region }\end{array}$ & $\begin{array}{l}0.321^{\star \star *} \\
(0.042)\end{array}$ & $\begin{array}{l}0.274^{* \star *} \\
(0.038)\end{array}$ & $\begin{array}{l}0.278^{* * *} \\
(0.038)\end{array}$ \\
\hline $\begin{array}{l}10 \text { year real GDP } \\
\text { Volatility }\end{array}$ & $\begin{array}{c}33.073^{\star \star \star} \\
(8.416)\end{array}$ & $\begin{array}{c}34.734^{* * *} \\
(8.592)\end{array}$ & $\begin{array}{c}34.868^{* * *} \\
(8.509)\end{array}$ \\
\hline $\begin{array}{l}\text { Dummy for budget } \\
\text { balance rule }\end{array}$ & $\begin{array}{c}0.629 \\
(0.501)\end{array}$ & & \\
\hline $\begin{array}{l}\text { Gross debt to GDP * dummy } \\
\text { for debt rule }\end{array}$ & & $\begin{array}{l}-2.509 \\
(3.184)\end{array}$ & \\
\hline Constant & $\begin{array}{l}-6.623^{* * *} \\
(0.698)\end{array}$ & $\begin{array}{l}-6.561^{* * *} \\
(0.695)\end{array}$ & $\begin{array}{c}-6.516^{* * *} \\
(0.689)\end{array}$ \\
\hline Observations & 531 & 531 & 531 \\
\hline Log Likelihood & -130.497 & -128.007 & -128.354 \\
\hline Akaike Inf. Crit. & 278.993 & 276.014 & 274.709 \\
\hline
\end{tabular}

Note: Asterisks $\left({ }^{*},{ }^{* *},{ }^{* * *}\right)$ indicate the significance level $(10 \%, 5 \%, 1 \%)$ of the coefficients. Explanatory variables are lagged by one year. The dependent variable is a dummy variable equal to one when the country is in sovereign default (either on domestic or external debt). 
ECO/WKP(2018)41

Table A1.7. World Governance Indicators

\begin{tabular}{ll}
\hline \multicolumn{1}{c}{ Variable } & \multicolumn{1}{c}{ Definition } \\
\hline The process by which governments are selected, monitored, and replaced \\
Coice and accountability & $\begin{array}{l}\text { Capturing perceptions of the extent to which a country's citizens are able to } \\
\text { participate in selecting their government, as well as freedom of expression, } \\
\text { freedom of association, and a free media. }\end{array}$ \\
$\begin{array}{l}\text { Political stability and absence } \\
\text { of violence/terrorism }\end{array}$ & $\begin{array}{l}\text { Capturing perceptions of the likelihood that the government will be } \\
\text { destabilized or overthrown by unconstitutional or violent means, including } \\
\text { politically-motivated violence and terrorism. }\end{array}$ \\
\hline The capacity of the government to effectively formulate and implement sound policies \\
Capturing perceptions of the quality of public services, the quality of the \\
civil service and the degree of its independence from political pressures, \\
the quality of policy formulation and implementation, and the credibility of \\
the government's commitment to such policies.
\end{tabular}

Source: Kaufmann, D., A. Kraay and M. Mastruzzi (2011): "The Worldwide Governance Indicators: Methodology and Analytical Issues", The Hague Journal of Rule of Law. 
Table A1.8. List of variables

\begin{tabular}{ll}
\hline \multicolumn{1}{c}{ Variable } & \multicolumn{1}{c}{ Source } \\
\hline Sovereign defaults & Reinhart and Rogoff (2009) \\
\hline Exchange rate regime & Reinhart and Rogoff (2009) \\
\hline Government effectiveness & World Governance Indicators \\
\hline Rule of law & World Governance Indicators \\
\hline Regulatory quality & World Governance Indicators \\
\hline Voice and accountability & World Governance Indicators \\
\hline Political stability and absence of violence & World Governance Indicators \\
\hline Control of corruption & World Governance Indicators \\
\hline GDP in PPP & World Economic Outlook (IMF) \\
\hline GDP per capita & World Economic Outlook (IMF) \\
Real GDP growth & World Economic Outlook (IMF) \\
\hline Openness ratio & World Economic Outlook (IMF) \\
\hline Primary balance to GDP & World Economic Outlook (IMF) \\
Population & World Economic Outlook (IMF) \\
\hline 10 year Terms of trade volatility & World Economic Outlook (IMF) \\
\hline Interest payments to exports & World Economic Outlook (IMF) \\
\hline Revenue to GDP & World Economic Outlook (IMF) \\
\hline Exchange rate & World Economic Outllok (IMF) \\
Interest payment to exports & World Economic Outlook (IMF) \\
\hline 10 year GDP volatility & Penn World Table \\
\hline Debt to GDP & Historical public debt database (Abbas et al. 2010) \\
\hline Oil and Mining exports to GDP & World Trade Organization \\
\hline Fiscal rules & Fiscal Rules Dataset (IMF) \\
\hline
\end{tabular}


ECO/WKP(2018)41

\section{REFERENCES}

Abbas, S. M. A., N. Belhocine, A. ElGanainy and M. Horton (2010) "A Historical Public Debt Database", IMF Working Paper, No. 10/245, International Monetary Fund.

Acemoglu, D., S. Johnson and J. A. Robinson (2005), "Institutions as a Fundamental Cause of Long-run Growth", in: Handbook of Economic Growth, Vol. 1A, edited by P. Aghion and S. N. Durlauf.

Akgun, O., D. Bartolini and B. Cournède (2017), "The Capacity of Governments to Raise Taxes", OECD Economics Department Working Papers, No. 1407, OECD Publishing, Paris.

Arellano, C., Y. Bai and S. Lizarazo (2017), “Sovereign Risk Contagion”, Federal Reserve Bank of Minneapolis, Research Division Staff Report, No. 559.

Bi, H. (2012), "Sovereign Default Risk Premia, Fiscal Limits, and Fiscal Policy", European Economic Review, Vol. 56, Issue 3, pp.389-410.

Bi, H. and E. M. Leeper (2013), "Analysing Fiscal Sustainability”, Bank of Canada Working Paper, 201327, Ottawa.

Blanchard, O. et al. (1990), "The Sustainability of Fiscal Policy: New Answers to an Old Question", OECD Economic Studies, No. 15, Autumn, Paris.

Botev, J., J.-M. Fournier and A. Mourougane (2016), "A Reassessment of Fiscal Space in OECD Countries", OECD Economics Department Working Papers, No. 1352

Catão, L. and S. Kapur (2004), "Missing Link: Volatility and the Debt Intolerance Paradox," IMF Working Papers, No. 04/51, International Monetary Fund.

Cohen, D. and C. Valadier (2011), "40 Years of Sovereign Debt Crises", CEPR Discussion Paper, No. DP8269. Available at SSRN: https://ssrn.com/abstract=1782563

Cole, H. L. and T. J. Kehoe (2000), "Self-Fulfilling Debt Crises", Review of Economic Studies, Vol. 67, No. 1, pp. 91-116.

Cruces, J. J. and C. Trebesch (2013) "Sovereign Defaults: The Price of Haircuts", American Economic Journal: Macroeconomics, 5(3): 85-117. DOI: 10.1257/mac.5.3.85

Faria, A. and P. Mauro (2009), "Institutions and the External Capital Structure of Countries", Journal of International Money and Finance, Vol. 28, No. 3, pp. 367-391.

Fournier, J.-M. and M. Bétin (2018), "Sovereign Default: Evidence on the Importance of Government Effectiveness", OECD Economics Department Working Paper, No. 1494, OECD Publishing, Paris. 
Fournier, J.-M. and F. Fall (2017), "Limits to Government Debt Sustainability in OECD Countries", Economic Modelling, Vol. 66, pp. 30-41.

Gandelman, N. and R. Hernández-Murillo (2014), "Risk Aversion at the Country Level", Federal Reserve Bank of St. Louis Working Paper Series, No. 2014-005B.

Ghosh, A. R. et al. (2013), "Fiscal Fatigue, Fiscal Space and Debt Sustainability in Advanced Economies", Economic Journal, Vol. 123, pp. 4-30.

Hilscher, J. and Y. Nosbusch (2010), "Determinants of Sovereign Risk: Macroeconomic Fundamentals and the Pricing of Sovereign Debt", Review of Finance, Vol. 14(2), pp. 235-262.

Kaufmann, D., A. Kraay and M. Mastruzzi (2011): "The Worldwide Governance Indicators: Methodology and Analytical Issues", The Hague Journal of Rule of Law.

Kohlscheen, E. (2007), "Why Are there Serial Defaulters? Evidence from Constitutions", Journal of Law and Economics, Vol. 50, pp. 713-730.

Moody’s (2008), “Sovereign Default and Recovery Rates, 1983-2007”, Special comment, Moody’s Investors Service.

Kraay, A. and V. Nehru (2006), “When Is External Debt Sustainable?", World Bank Economic Review, No. 20, pp. 341-365.

Panizza, U., F. Sturzenegger and J. Zettelmeyer (2009), "The Economics and Law of Sovereign Debt and Default”, Journal of Economic Literature, Vol. 47, No. 3, pp. 651-98.

Reinhart, C. M. and K. S. Rogoff (2009), This Time Is Different, Eight Centuries of Financial Folly, Princeton University Press.

Reinhart, C. M., K. S. Rogoff, and M. A. Savastano (2003), “Debt Intolerance”, Brookings Papers on Economic Activity, 34, pp. 1-74.

Reisen, H. and S. Ndoye (2008), "Prudent versus Imprudent Lending to Africa: From debt relief to emerging lenders", OECD Development Centre Working Papers, No. 268, OECD Publishing, Paris.

Viennot, M. (2017), Crise financière, accumulation de dette et défault souverain, Thèse de L'Ecole des Hautes Etudes en Science Sociales.

Villemot, S. (2012), Essays on Modelling the Sovereign Default Risk, Thèse de l'Ecole des Hautes Etudes en Sciences Sociales. 